IZA DP No. 5437

Manager Ethnicity and Employment Segregation

Laura Giuliano

Michael Ransom

January 2011 


\title{
Manager Ethnicity and Employment Segregation
}

\author{
Laura Giuliano \\ University of Miami \\ Michael Ransom \\ Brigham Young University \\ and IZA
}

\section{Discussion Paper No. 5437 \\ January 2011}

\author{
IZA \\ P.O. Box 7240 \\ 53072 Bonn \\ Germany \\ Phone: +49-228-3894-0 \\ Fax: +49-228-3894-180 \\ E-mail: iza@iza.org
}

\begin{abstract}
Any opinions expressed here are those of the author(s) and not those of IZA. Research published in this series may include views on policy, but the institute itself takes no institutional policy positions.

The Institute for the Study of Labor (IZA) in Bonn is a local and virtual international research center and a place of communication between science, politics and business. IZA is an independent nonprofit organization supported by Deutsche Post Foundation. The center is associated with the University of Bonn and offers a stimulating research environment through its international network, workshops and conferences, data service, project support, research visits and doctoral program. IZA engages in (i) original and internationally competitive research in all fields of labor economics, (ii) development of policy concepts, and (iii) dissemination of research results and concepts to the interested public.
\end{abstract}

IZA Discussion Papers often represent preliminary work and are circulated to encourage discussion. Citation of such a paper should account for its provisional character. A revised version may be available directly from the author. 
IZA Discussion Paper No. 5437

January 2011

\section{ABSTRACT \\ Manager Ethnicity and Employment Segregation*}

Using nine years of personnel records from a regional grocery store chain in the United States, this study examines the effect of manager ethnicity on the ethnic composition of employment at the firm's 73 stores. We estimate separate models with store fixed effects for several departments and job titles at each store. We first compare the rates at which Hispanic employees are hired under Hispanic and non-Hispanic, white managers, and then examine the effects of manager-employee ethnic differences on separations and on transfers between stores. We find significant effects of manager ethnicity on hiring patterns in the four job positions that are in small departments, but not in the two positions in larger departments. Manager-employee ethnic dissimilarity has no significant effects on transfers, and affects rates of employee separations in only one case.

JEL Classification: J71

Keywords: ethnicity, segregation, managerial discretion

Corresponding author:

Michael Ransom

Department of Economics

143 FOB

Brigham Young University

Provo, UT 84602

USA

E-mail: ransom@byu.edu

${ }^{*}$ For helpful comments we thank John Treble and session participants at the 2008 WEAI and the 2009 SOLE meetings 
As both American managers and their employees grow more ethnically diverse, it is increasingly important to understand whether manager ethnicity affects the ethnic composition of an establishment's workforce. It is well established that there is a substantial degree of ethnic segregation across U.S. workplaces. While this segregation results partly from residential segregation and from segregation by ethnically correlated skills, other mechanisms are likely to be important (Hellerstein and Neumark, 2008). One possibility is that ethnic segregation of employees is directly linked to ethnic differences between managers. Several factors could cause such a link: discrimination by managers or employees, production complementarities due to shared language or culture, and ethnically segregated labor market networks.

Using nine years of personnel records from a regional grocery store chain in the United States, this study examines the role of manager ethnicity on the ethnic composition of employment at the firm's 73 stores. We look at the effects of ethnic dissimilarity on new hires, separations, and transfers between stores. And we compare the effects of dissimilarity across several departments and job titles at each store. The workforce we study is primarily white, but has a large Hispanic minority and very few members of other race or ethnic groups. Hence, our focus is on the role of Hispanic ethnicity.

To be sure, we analyze data from only a single employer, and our study faces the usual limitation of such case studies in that we cannot know how well our results may generalize to other firms and other industries. However, the detail provided by personnel data is crucial to studying the question at hand. In large representative data sets, it is generally not possible to match managers with their employees and to observe the flow of employment in and out of workplaces over time.

The data set also has several other valuable features. First, it has large numbers of Hispanics not only among employees, but also in managerial positions. Despite the growing importance of Hispanics in the U.S. labor force, there has been relatively little work on ethnicity in the U.S. labor market. The Hispanic presence in our data set allows us to focus on this understudied group.

Second, because we have several years of data on each store and because there are several departments within each store, we observe multiple managers at each of the firm's workplaces. 
Moreover, there is substantial within-store variation in manager ethnicity both over time and across departments. This is important because manager ethnicity may be correlated with several characteristics of a workplace that affect the ethnic composition of employees (e.g., skill requirements and the demographics of the local labor pool), and such workplace characteristics are typically unobserved. By examining variation in manager ethnicity that occurs within stores, we can control for all such unobserved differences across workplaces.

Third, because each store has several departments and job titles, we are able to compare the effects of ethnic dissimilarity for six different positions within the store-courtesy clerks (baggers), cashiers, stockers, meat wrappers, meat cutters, and produce clerks. Fourth, we are able to separately analyze employment flows into and out of the store, and to distinguish changes in firm employment (new hires and separations) from changes in store employment due to transfers between stores. These last two features allow us to compare the effects of manager ethnicity and ethnic differences for different job types and different employment outcomes, and hence we can gain some insight into both the underlying reasons for the relationships that we find and the applicability of the results to other jobs and sectors.

We find significant differences in hiring patterns between Hispanic and non-Hispanic managers in the four job positions that are in small departments, but not in the two positions in larger departments. Further, we find that manager ethnicity has no significant effects on transfers, and affects rates of employee separations in only one case.

Our results show, first, that more Hispanics are hired under Hispanic managers than under nonHispanic managers when hiring for the four positions that are in small departments: bagger, meat wrapper, meat cutter, and produce clerk. These positions differ from the two that are not affectedcashiers and stockers-in that their numbers are much smaller; there are typically between one and three employees in each of the former positions vs. six to eight in the latter. We examine below why ethnicity may affect hiring patterns at our firm; some of our results suggest managerial discrimination or hiring networks, other results point to production complementarities. We also discuss why ethnic differences affect hiring patterns in only the small departments. 
Our results show, second, that in no case does manager ethnicity affect the probability that an employee transferring from another store is Hispanic. Finally, our findings show that ethnic differences between managers and employees have significant effects on rates of employee separations in only one case: cashiers. We discuss below what may distinguish cashiers from the other positions.

\section{Literature Review}

In a comprehensive study of workplace segregation in the U.S., Hellerstein and Neumark (2008) document extensive segregation by race and by Hispanic ethnicity. Their database allows them to construct measures of segregation that are representative of most U.S. workplaces by matching records in the 1990 Decennial Census of Population to a Census Bureau list of most U.S. business establishments. However, their data lacks detailed information on individuals and establishments, and does not match employees to their managers. Hence their ability to determine the sources of segregation is limited, and they cannot examine the link between manager race or ethnicity and the racial and ethnic composition of employees.

Using a variety of data sets that match employees with their managers, a handful of valuable studies have looked at the question of whether segregation of employees is directly linked to differences between managers. Four studies that focus on black employment in the U.S.-Stoll, Raphael and Holzer (2004), Carrington and Troske (1998), Turner (1997), and Bates (1994)—all find that blacks are employed at greater rates in establishments with black supervisors, managers, or owners. A disadvantage of these studies, however, is that none can control for unobserved differences across workplaces that may be correlated with manager race (e.g., skill requirements and the demographics of the local labor pool). Hence these studies have limited ability to conclude that variation in manager race is an important source of segregation.

Three recent studies estimate the effects of manager demographics on workforce demographics by examining changes in management over time in order control for unobserved workplace characteristics. One study, by Aslund, Hensvik and Nordstrom (2009), analyzes panel data from a Swedish linked employer-employee database and finds that immigrant managers are substantially more 
likely to hire immigrants than are native managers. ${ }^{1}$ The Swedish data set has the advantage of being representative of small and medium-sized workplaces in Sweden. An important disadvantage, however, is that in most of firms, the "managers" cannot be identified by job title; hence the authors must assume that the employee with the highest wage is the establishment's manager.

Two other studies that analyze changes in management—both by Giuliano, Leonard, and Levine (2009a, 2009b) — are more closely related to ours in that they use a panel data set constructed from the personnel records of a U.S. retail chain. These two studies examine, respectively, the effects of manager race and ethnicity on hiring patterns, and the effects of racial and ethnic differences between manager and employee on rates of employee turnover and promotions. The first of these papers finds that hiring patterns vary significantly across managers of different racial and ethnic groups. The largest differences are between black and non-black managers; but in locations with large Hispanic populations, Hispanic managers hire significantly more Hispanics and fewer whites than do white managers. The second paper finds that when the manager is a different race or ethnicity, both black and Hispanic employees are more likely to be fired and less likely to be promoted. It also finds small effects of ethnic differences on the quit rates of Hispanics and of whites. Overall, the findings of these two papers suggest that the racial and ethnic composition of a workforce is partly determined both by manager preferences for similar employees and by employee preferences for similar managers.

Apart from the two studies by Giuliano et al., we know of no other study that examines the importance of manager ethnicity for Hispanic labor market outcomes. ${ }^{2}$ Kenney and Wissoker (1994) examine the importance of hiring discrimination for Hispanics by analyzing data from an audit study, in which pairs of Hispanic and Anglo auditors with similar skills apply for the same low-skill, entry-level

\footnotetext{
${ }^{1}$ Aslund et al. (2009) also find that separations are more frequent when workers and managers have dissimilar origins; however the analysis of separations relies only on cross-sectional variation in manager origin, so it is questionable whether the estimated effects can be interpreted as causal.

${ }^{2}$ Other papers have studied the importance of racial and ethnic dissimilarity in other types of superior-subordinate relationships. Antonovics and Knight (2009) find that racial or ethnic similarity of police officer to driver reduces vehicle search rates; and Dee (2005) finds that racial or ethnic dissimilarity between students and teachers causes teacher evaluation of students to be more negative. However, while both of these studies include Hispanics, they both group Hispanics together with blacks; hence neither estimates separate effects of ethnic dissimilarity for Hispanics.
} 
positions with advertised vacancies. They find that Hispanic auditors were less likely than their Anglo counterparts both to obtain job interviews and to be offered jobs. However, presumably because of insufficient variation, they do not look at the role of employer or interviewer ethnicity.

\section{Data}

The data we analyze are the administrative personnel records from a large regional grocery store chain in the United States. The records cover a nine-year period from 1976 to 1984, and they contain information on every retail employee employed at each of the firm's stores as of December $31^{\text {st }}$ of each year.

Each year in the sample period, the firm operated between 57-61 retail stores located in 24 cities, and roughly 60 percent of the stores were concentrated in a single major metropolitan area. The firm closed several stores and opened several others during this period. As a result, our sample includes data on a total of 73 stores, with an average of 7.3 years of data per store, forming a panel of 532 store-years.

Table 1 summarizes the salient characteristics of the stores. A typical store had about 29 retail employees. The average workforce was predominantly white and non-Hispanic (82 percent), but had a sizeable minority of Hispanics (15 percent). The remaining three percent were classified as black, Asian, or Native American, and are grouped together here under the category called "non-white". The share of Hispanics in the workforce reflected the local demographics. Of the population living in Census tracts within one mile of a store, an average of 13.4 percent were Hispanic. Census data also show that an average of 5.6 percent of the local adult population were foreign born and that 1.6 percent were Spanishspeakers with limited English proficiency.

With the exception of three salaried managerial positions, all of the jobs in our analysis were covered by collective bargaining agreements. ${ }^{3}$ The union agreements addressed pay levels, work scheduling, holidays, vacations, and other benefits. However, importantly for our analysis, the employer retained full control over hiring and job allocation. When filling a vacancy, the employer was free to fill

\footnotetext{
${ }^{3}$ Most employees were represented by local affiliates of the United Food \& Commercial Workers Union, International, but meat department employees were represented by a different union. Our information is based on examination of one of the contracts. For more details, see Ransom and Oaxaca (2005).
} 
the position with a newly hired employee and was contractually obligated only to inform the union who was hired. In the case where the firm decided to fill a vacancy through internal promotion, the union contract required only that the most senior employee in the relevant source job be considered for the job. Thus the unions did not play a significant role in hiring, job assignment, or the assignment of managers at this company.

Figure 1 presents a simple organization chart for the firm. ${ }^{4}$ Each store had three salaried positions — the store manager, the assistant manager, and the relief manager. In addition, there were three other positions whose job titles suggest managerial responsibilities: the night crew chief and the managers of the meat and produce departments. These latter three positions were in the bargaining unit and thus were not technically part of store management. For simplicity, however, we will often refer to all six positions as "management."

Of these six positions, the store manager had the most authority with respect to employment decisions. But even the store manager's authority was limited. According to our interview with an individual who worked as a store manager for this employer during this time period, store managers had authority to hire only baggers (see below); other employees were hired at the corporate level and assigned to the store. Furthermore, transfers from one store to another could only be determined at a level of management above the store level. Although we do not know the exact responsibilities of the three nonsalaried managers, it is very unlikely that they had any authority over employment decisions. However, they may have been consulted by management regarding the hiring, firing, and transferring of employees in their departments.

The employees we study worked in one of four departments: front-end, stocking, meat, and produce. Employees with the job title of "food clerk" worked either in the front-end operating the cash registers (henceforth "cashiers") or in the stocking department stocking shelves (henceforth "stockers"). These two positions made up the bulk of employees, with a typical store averaging 8 cashiers and 6.4 stockers (Table 1). Courtesy clerks, who bagged and carried groceries for customers (henceforth

\footnotetext{
${ }^{4}$ This figure is a slightly modified version of Figure 1 from Ransom and Oaxaca (2005).
} 
"baggers"), were also in the front-end department. Each store employed 3.2 baggers on average. The meat department had two non-managerial positions: meat cutters (two per store on average) and meat wrappers (one per store on average); and the produce department had produce clerks (1.6 per store on average) who stocked the produce.

In addition to these four departments, most stores also had a variety (non-foods) department that typically had only one employee and no manager, and a few stores had other specialized departments such as a bakery. Our analysis excludes employees in these departments due to the small sample sizes.

Our analysis requires matching each employee with his or her managers each year. The manager we are most interested in is the one who supervised the employee directly. For front-end employees (baggers and cashiers), the store manager is considered the direct supervisor. Stockers are assigned to the night crew chief, and employees in the produce and meat departments are assigned to their respective department managers. ${ }^{5}$ We also match every employee to each of the salaried managers in the store.

When matching employees to managers, there are two situations in which there is some ambiguity about how to proceed. First, there are cases in which the managerial position is vacant on Dec. $31^{\text {st }}$ of the year (i.e. no employee is assigned the managerial job code). ${ }^{6}$ Second, matching of managers to employees is also ambiguous in cases when an employee's manager as of Dec. $31^{\text {st }}$ is replaced by a new manager sometime during the following year.

With respect to missing managers, if it is the store manager position that is vacant, we use the assistant manager. If it is a department manager that is vacant, there is no assistant manager so we need another solution. Our solution to missing department managers depends on whether we are analyzing new hires or separations. So too in the cases where there are new managers. When analyzing new hires,

\footnotetext{
${ }^{5}$ In the case of stockers, our matching is imperfect because we do not have data on shifts and thus do not know whether there are some stockers who do not work the night shift. We have experimented with assigning stockers to the relief manager instead and in general, doing so does not lead to different conclusions.

${ }^{6}$ About 10 percent of store-years are missing one of the three salaried managers, but very few are missing more than one. Assistant and relief managers are missing with about the same frequency as are store managers. Also, roughly seven percent of meat and produce managers are missing. The frequency with which these managers are missing is not correlated with store employment and the manager vacancies are temporary. The case of night crew chiefs is different. About 30 percent of store-years are missing a night crew chief, and many of these are consecutive years in the same store. The frequency with which stores lack night crew chiefs is highly correlated with store employment, suggesting that smaller stores often do not employ one.
} 
our solution to the missing manager cases is to replace them with the previous manager in the store. And in the case of manager changes, we retain the current manager. When analyzing separations, our solution to both the missing managers and the changes in manager is to match the employee to the department manager who is observed in the following year. Because we do not have data on separation dates, the following year's manager is at least as likely as the current manager to have affected employee separation rates during the following year. Indeed, if employees have some prior knowledge of changes in management, then the future manager is probably the more relevant of the two. For this reason, we use the next year's manager in cases where there is a change. ${ }^{7}$

When matching employees in one year to the manager in the following year, we must take into consideration the fact that one of this year's employees may be next year's manager. To avoid designating an employee as his or her own manager, we exclude from our estimation sample employees who were promoted to manager within their own department.

\section{Employee characteristics}

Table 2 provides summary statistics for the employees in our sample. There are several systematic differences in employee characteristics across jobs. The fraction Hispanic is smaller in the job categories with more employees (cashiers and stockers have 13.1 and 15.4 percent respectively) and is largest among the produce clerks (26.5 percent). There is substantial segregation of jobs by gender: cashiers and meat wrappers are almost entirely female, while stockers, meat cutters and produce clerks are predominantly male. There are also large age differences: baggers are the youngest employees (average age of 19), and cashiers and meat department employees are the oldest (38-43 years).

Wage rates are shown as of Dec. 31,1980 . These ranged from $\$ 2.90$ (close to the minimum) for baggers to $\$ 8.90$ for meat cutters. Produce clerks, cashiers, and stockers had an average wage of $\$ 7.30$, and these three had the same union pay scale that encompassed several different pay rates based on

\footnotetext{
${ }^{7}$ Roughly 15 percent of store-years remain without a night crew chief. In these cases, we have experimented with assigning the relief manager as the stockers' manager. In general, our conclusions do not change.
} 
seniority. ${ }^{8}$ As expected, average tenure is highly correlated with wage rates, and is lowest among baggers whose average tenure is less than one year.

\section{Manager characteristics}

Table 3 summarizes the characteristics of our managers. The degree of ethnic diversity differs considerably across the managerial positions. Only 2.5 percent of store managers are Hispanic, but the Hispanic share increases to 6.5 for assistant managers, 10.7 percent for relief managers, and 17.7 for night crew chiefs. And, as is true of non-managerial employees, the Hispanic share of managers is highest in the meat and produce departments, with produce managers having the largest share (29.6 percent). Only about one percent of all managers are classified as non-white (black, Asian, or Native American).

It is also notable that there are very few female managers at any level. Indeed, during the latter part of the sample period, the employer faced a class action lawsuit over gender differences in promotion and pay. ${ }^{9}$

Store-level managers — store manager, assistant manager, and relief manager — typically earned substantially more than other employees. The one exception is that the average earnings of the meat department manager were greater than those of the assistant or relief managers. Night crew chiefs and produce managers earned less than relief managers, but had a wage premium of about 13 percent over food and produce clerks.

While managers typically have between six and sixteen years of tenure, there is considerable turnover within each position due to a combination of separations, promotions, and transfers of managers between stores. The probability that a manager is replaced in a given year is about 31.5 percent for store managers and night crew chiefs, 40 percent for assistant and relief managers, and 26.6 percent for meat and produce managers. In nearly all cases, the managerial vacancies are filled through promotions or transfers; only two percent of those in our sample were filled through new hires.

The churning of managers is important for our analysis because it provides one source of

\footnotetext{
${ }^{8}$ These wage rates exclude night shift or overtime premia.

${ }^{9}$ Ransom \& Oaxaca (2005) examine the lawsuit's impact on gender differences in promotions and pay.
} 
variation in manager ethnicity within stores. Within the time frame of our data, 90 percent of the stores have at least one change in the identity of the highest-ranked salaried manager (store manager, or assistant manager if the store manager is missing); and 10 percent of stores have some time-series variation in the ethnic classification of this manager. There is more time-series variation in the ethnicity of the relief managers, night crew chiefs, and the meat and produce managers. For each managerial position, more than a quarter of all stores have both a Hispanic and a non-Hispanic white filling the position during our sample period.

Our analysis also exploits a second source of within-store variation in manager ethnicity: that which is due to ethnic differences between department managers in the same store and year. There is substantial variation here, especially among night crew chiefs, meat managers and produce managers. In 40 percent of our store-year observations, there is some ethnic variation among the night crew, meat, and produce managers; and in 30 percent, the produce manager's ethnicity differs from that of the meat manager.

\section{Measures of Ethnic Dissimilarity}

To measure the ethnic relationship between employees and their managers, we construct a dummy variable that is equal to one if an employee's manager is a different ethnicity. This variable is summarized in the second panel in Table 2. On average, approximately 18 percent of all baggers and cashiers work in a store where their supervisor (i.e. the highest-ranking salaried manager) is a different ethnicity. Because most store managers are non-Hispanic whites, this group is composed mainly of Hispanic employees with non-Hispanic managers.

Among employees supervised by non-salaried department managers, the fraction with dissimilar managers is much higher, and it is also more evenly split between Hispanics and non-Hispanics. Among stockers, 22 percent have a dissimilar night crew chief; and roughly 33 percent of meat and produce employees have a dissimilar department manager. Breaking these statistics down by employee ethnicity, we see that among this group there are at least as many non-Hispanics with Hispanic managers as there are Hispanics with non-Hispanic managers. 
Though many employees have dissimilar managers, there is nevertheless a tendency for managers and their employees to be of the same ethnicity. This can be seen in Table 4, which compares the ethnic composition of employees under non-Hispanic and Hispanic managers. On average, the proportion of employees that is Hispanic is 13.5 percent among those with non-Hispanic managers, but is nearly three times as high (39.2 percent) among those with Hispanic managers. The difference in demographics between the employees of non-Hispanic managers and those of Hispanic managers is especially high among baggers.

Much of the correlation between manager and employee ethnicity is likely to result from the residential segregation of Hispanics and non-Hispanics. Hence, to investigate the role of residential segregation, we collected 1980 U.S. Census data on the Hispanic share of the population living within one mile of each store, and merged this data with data from the cross-section of stores in our sample that were open in $1980 .{ }^{10}$ We then estimated linear probability models predicting the probability that an employee is Hispanic as a function of both the ethnicity of the employee's manager and the Hispanic share of the population living near the employee's store. The results (Table 5) confirm the importance of residential segregation. The coefficient on the Hispanic population share is always significant and large, and it is especially large in the analysis of baggers-who tend to live much closer than other employees to the stores where they work. ${ }^{11}$ However, even after controlling for the ethnic composition of the local population, manager ethnicity remains a significant predictor of the workforce's ethnic composition. The coefficients on manager ethnicity are especially large in the analyses of baggers and of meat and produce employees.

It is possible that even the residual correlation between manager and employee ethnicity is driven by residential segregation and the resulting differences in local labor pools; after all, our Census measures provide only an imperfect measure of labor pool differences across stores. However, this residual

\footnotetext{
${ }^{10}$ More precisely, we use data on the population living in all Census tracts that lie within a one-mile radius of each store.

${ }^{11}$ Residential ZIP codes are available for a subset of employees in our data. Using these ZIP codes, we estimated that baggers commute an average of 3.7 miles to their workplaces while other non-managerial employees commute between eight and eleven miles on average.
} 
correlation could also result if (1) more Hispanic employees are hired under Hispanic managers than under non-Hispanic managers, or (2) employees whose ethnicity is different from the ethnicity of their managers have higher separation rates than employees who are ethnically similar to their managers. We examine the latter two hypotheses in our regression analysis below.

\section{Measures of Employment Flows}

The bottom panel of Table 2 describes the flow of employment in and out of each job title. There is very little movement between departments within a store. Otherwise, there are three ways that employees enter a job: hires, transfers from the same position at another store, and promotions. There are also three ways that employees exit a job: separations from the company, transfers to the same job at another store, and promotions (which may involve transfers between departments or stores).

The main focus of our analysis is on employment flows in and out of the firm, and hence we are interested in new hires and separations. The probability that a given employee was hired within the past year is largest among baggers at about 68 percent. For all other positions, it is between seven and ten percent. Our sample contains a total of more than 2000 new hires into the six job titles we examine. The probability that an individual's employment with the company is terminated within a year is again highest for baggers at 45 percent, and ranges from 10 to 17 percent for employees in the other positions. ${ }^{12}$ Our data set documents roughly 1700 separations from job titles we examine. ${ }^{13}$

There is very little movement between departments-except for baggers moving to stocking and produce when promoted, and the movement of produce clerks into the stocker position (about 10 percent per year). However, with the exception of baggers, transfers between stores within same job title were common. The probability that a (non-bagger) employee is found in the same job but a different store one

\footnotetext{
${ }^{12}$ Because we don't observe employees who were hired after Jan. $1^{\text {st }}$ and separated before Dec. $31^{\text {st }}$ of a given year, estimates based on our sample are likely to underestimate true turnover rates. The sample selection bias in our estimates of turnover rates is likely to matter most for baggers. We discuss this issue further below.

${ }^{13}$ Separations are inferred from the fact that the employee was not present in the following year. For stores that closed, we exclude employees in the year before closing. We also exclude observations from the last year of our sample period (Dec. 31, 1984).
} 
year later ranges from nine percent for produce clerks to 20 percent for meat cutters. ${ }^{14}$

With regard to movement through promotions (in-store and transfer promotions), each year 26 percent of baggers are promoted to stocker, cashier, or produce clerks; 7.5 percent of stockers are promoted to night crew chief or relief manager; 2.3 percent of meat employees are promoted to meat cutter; and roughly 5 percent of meat cutters and produce clerks are promoted to the managerial position in their respective departments.

\section{Manager Ethnicity and Hiring Patterns}

In estimating the effect that manager ethnicity has on the ethnic composition of new hires, a key challenge is that the characteristics of both managers and employees may be correlated with other characteristics of a workplace and its location. In our data, job descriptions and skill requirements are highly uniform across workplaces. So the main concern is variation in the ethnic composition of the labor pool due to the residential segregation of ethnic groups. As Table 5 suggests, stores located in Hispanic neighborhoods are likely to have more Hispanic managers and hire more Hispanic employees simply because both managers and employees have a preference for working close to where they live. Because we do not have precise measures of the ethnic composition of each store's labor pool, we cannot identify the role of manager ethnicity by making comparisons across stores.

Our identification strategy, therefore, is to exploit variation in manager ethnicity that occurs within stores. There are two sources of such variation in our data. The first is time-series variation that arises due to manager turnover-such as when a Hispanic manager replaces a non-Hispanic manager or vice versa. The second source of within-store variation is the ethnic differences between contemporaneous managers of different departments in the same store.

We start by using the time-series variation to estimate a model with store fixed effects. Our basic estimation equation is a linear probability model in which the dependent variable is a dummy variable that is equal to one if an employee $i$, hired in store $j$ at time $t$, is Hispanic:

(1) $\operatorname{Pr}\left(\right.$ Hispanic $\left._{i j t}=1\right)=\alpha+\beta M g r \_$Hispanic ${ }_{j t}+X_{j t} \gamma+T_{t} \delta+\mu_{j}+\varepsilon_{i j t}$.

\footnotetext{
${ }^{14}$ Employees in stores that close are excluded from this measure.
} 
The parameter of interest is the coefficient $\beta$ on a dummy variable (Mgr_Hispanic) that equals one if the manager is Hispanic in the department where the new hire occurs. ${ }^{16}$ The store fixed effects, $\mu_{j}$, summarize the effects of any permanent differences across stores, communities, and local labor markets on the probability that a new hire is Hispanic. The equation also includes a set of dummy variables, $T_{t}$, that corresponds to eight of the nine years in our sample. These year identifiers control for changes over time in labor supply and demand that might affect the ethnic composition of the labor pools for all stores. Finally, $X_{j t}$ represents a vector of covariates that vary within stores over time.

We estimate several versions of equation (1). In each case, we estimate the equation separately for baggers, cashiers, and stockers, but we pool employees in the meat and produce departments in order to increase our sample size and boost the precision of our estimates. When using the meat and produce sample, we also control for dummy variables indicating the position (meat wrapper, meat cutter, or produce clerk) for which the employee is being hired.

In our most basic specification of equation (1), we include only three additional controls variables $\left(X_{j t}\right)$ : a dummy variable equal to one if the manager is non-white, a dummy equal to one if there is no store manager present, and the total number of salaried managers present. The omitted manager ethnicity category is "white, non-Hispanic"; hence $\beta$ compares the rates at which Hispanic employees are hired under Hispanic managers and white, non-Hispanic managers. ${ }^{17}$

The estimation results of this basic specification are shown in the first column of Table 6 . The estimated effect of having a Hispanic manager varies dramatically across jobs. For cashiers and stockers, the estimates are small and statistically insignificant. But for baggers and for meat and produce employees, we estimate large and statistically significant effects.

For baggers, the estimates imply a 52 percentage point difference in the rate that Hispanics are hired under Hispanic and non-Hispanic managers. In our sample, under a typical non-Hispanic manager

\footnotetext{
${ }^{16}$ As in Table 2, the department manager for baggers and cashiers is the store manager if one is present and the assistant managers otherwise.

${ }^{17}$ There are too few non-white managers to obtain reliable estimates comparing non-white groups to whites or Hispanics, and pooling the non-white managers with white managers does not change the Hispanic manager coefficients significantly.
} 
in a given store, an average of six non-Hispanic baggers are hired for every one Hispanic bagger. Thus our estimate means that replacing the non-Hispanic manager with a Hispanic manager would yield a dramatic change in this ratio-with one non-Hispanic bagger being hired for every two Hispanics hired.

In the case of meat and produce employees, the column (1) estimate implies that when a department manager is Hispanic, 26 percentage points more Hispanic employees are hired into that department. When the manager is non-Hispanic, roughly one out of every eight hires is Hispanic in a typical meat or produce department. Hence our estimate means that when the department manager is Hispanic, three out of every eight hires is Hispanic.

To test for differences among meat wrappers, meat cutters, and produce clerks, we also estimate a model that includes the interaction of Mgr_Hispanic with the job title indicators. While the results suggest that the effects of manager ethnicity are smaller for meat wrappers than they are for meat cutters and produce clerks, the differences are not statistically significant.

In column (1), the focal manager in the analysis of baggers and cashiers is the store manager (or assistant manager); and in the analysis of stockers, meat department employees and produce clerks, it is the relevant department manager (or crew chief). We estimate these effects as if the department managers had a role in hiring the employees in their departments, although we believe that such a role, if any, would be indirect. Our understanding is that for all employees except baggers, hiring decisions were made at a management level above the store level. However, members of store management may have played a role in this process. It is plausible that the store-level managers would be involved in (if not ultimately responsible for) the hiring of cashiers, stockers, and employees in the meat and produce departments. It is also plausible that the assistant or relief manager would be involved in the hiring of baggers even if a store manager is present.

In column (2), we explore these possibilities by including a variable measuring the fraction Hispanic among the store-level managers (store, assistant, and relief). This variable has a significant positive coefficient only in the case of meat and produce employees, suggesting that the ethnicity of the store-level managers is relevant in the meat and produce departments. However, the estimated effect of 
having a Hispanic department manager remains unchanged.

The fixed effect equations used in columns (1) and (2) control for permanent differences across stores and for time-series variation that is common to all stores. But they do not control for differences across stores that also vary over time. Hence if some determinants of hiring patterns varied both across stores and over time, the estimates resulting from equation (1) would be biased. For example, if trends in local demographics led to parallel trends in the applicant pool demographics of both managers and employees, then the fixed effects estimates would overstate the role of manager ethnicity in determining who gets hired.

To address this issue, we estimate three variations of equation 1. First, we include as controls two variables that serve as proxies for the share of Hispanics in the labor pool. These control variables are the Hispanic share of department managers and the Hispanic share of employees in all departments other than the one being analyzed. The logic of this specification is that the ethnic composition of different departments should be correlated to the extent that they all reflect the ethnic composition of the labor pool. We exploit the combination of time-series and inter-departmental variation in manager ethnicity to ask (for example): holding constant the ethnic composition of managers and employees in the rest of the store, do more Hispanic stockers get hired under Hispanic night crew chiefs than under non-Hispanic night crew chiefs?

The coefficients from this specification are shown in column (3). We find a significant coefficient on the new control variables in only one case- the negative coefficient on the Hispanic share of non-stocking department managers in the analysis of new hires for the stocker position. This negative coefficient implies that when there are more Hispanic managers in the meat and produce departments, the stocking department is less likely to hire Hispanics. A possible explanation is that when there are job openings in more than one department and when the meat or produce manager is Hispanic, Hispanic applicants tend to be hired as meat or produce workers and consequently are less likely to be hired as stockers.

In no case is the probability of hiring a Hispanic significantly correlated with the Hispanic share 
of employees in the rest of the store. And in no case does controlling for store demographics reduce the coefficient on Mgr_Hispanic. Hence the results in column (3) generally support the conclusion that the estimates from columns (1) and (2) are not driven by changes in the labor pools of stores, but instead reflect systematic differences in hiring patterns between departments with Hispanic and non-Hispanic managers.

Our second version of equation (1) includes store-specific trends in addition to store fixed effects. The estimates from this specification are shown in column (4), and can be interpreted as showing whether a change in the ethnicity of the manager leads to a deviation from the trend in the Hispanic share of the group being analyzed. However, our panel is relatively short and-except for baggers—we have a small number of observations per store. As a result, it is difficult to estimate store-specific trends with precision.

But in the analysis of baggers, we do have a reasonable degree of precision. Here the coefficient on $M g r \_H i s p a n i c$ remains very close to what it was in the first three specifications and also remains statistically significant. So here column (4) reinforces the conclusion drawn from the estimate in column (3). Within the same store and hiring from an ethnically similar labor pool, more Hispanic baggers are hired under Hispanic managers than under non-Hispanic managers.

When we include store-specific trends for the other positions, the coefficients on Mgr_Hispanic do change but the standard errors become much larger. As a result, none of the coefficients on Mgr_Hispanic is statistically different from zero. In the analysis of meat and produce employees, the positive coefficient drops from 0.26 (in the first three columns) to 0.18 and loses its statistical significance. Given the lack of precision, it is hard to draw firm conclusions from this result. But because the estimated coefficient remains positive and large, it is nevertheless consistent with the conclusion that manager ethnicity affects hiring patterns in the meat and produce departments.

To examine the meat and produce departments further, we perform a third test that exploits both inter-department variation in manager ethnicity and variation over time. Using only meat and produce employees, we estimate an equation that includes store-year fixed effects $\left(\mu_{j t}\right)$ : 
(2) $\operatorname{Pr}\left(\right.$ Hispanic $\left._{i j t}=1\right)=\alpha+\beta M g r \_H i s p a n i c_{i j t}+$ Meat_Cutter $_{i j t} \gamma+$ Produce_Clerk $_{i j t} \delta+\mu_{j t}+\varepsilon_{i j t}$

With $\beta$ constrained to be the same across the three job categories in the meat and produce departments, this model is identified off of store-years in which the meat manager is a different ethnicity from the produce manager. Because it controls for job title, this specification also exploits the fact that some storeyears have a non-Hispanic produce manager and a Hispanic meat manager, while in others the reverse is true. Thus a positive value for $\beta$ would indicate that more Hispanics are hired into the department with the Hispanic manager than into the department with the non-Hispanic manager.

The estimated coefficient is shown in column (5), and it is positive. While only marginally significant $(\mathrm{p}=.10)$, it is large in magnitude and suggests nearly a 60 percentage point difference between departments with Hispanic and non-Hispanic managers in the probability that a Hispanic employee is hired.

\section{Why and when do hiring patterns depend on manager ethnicity?}

We conclude from the analysis of new hires that in four of six job positions, Hispanics are significantly more likely to be hired if the manager is Hispanic. But this conclusion raises two additional questions. First, why do hiring patterns differ in departments with Hispanic and non-Hispanic managers? And second, why are differences observed for some jobs and not for others? Further analysis suggests that manager ethnicity affects the probability of hiring a Hispanic only in small departments (baggers, meat and produce). And while several factors could affect the hiring of baggers, production complementarities are likely the best explanation of our findings for meat and produce workers.

The differences in hiring patterns between Hispanic and non-Hispanic managers may be caused by three factors: discrimination, networks, and production complementarities. First, as in Becker's (1971) model, segregated hiring could result from taste-based discrimination either by managers or by employees. Since the next section will argue that employee discrimination is unlikely, this section will consider only managerial discrimination. Second, segregated hiring could also occur if segregated networks are used by managers searching for applicants and by employees searching for jobs. Finally, if manager-employee similarity improves productivity (e.g., because communication is facilitated by a 
shared language or culture), then employees who share the manager's ethnicity may be hired for efficiency reasons.

First, we look at which features distinguish the jobs in which hiring patterns are affected by manager ethnicity (baggers, meat wrappers, meat cutters, and produce clerks) from those where we find no effect (cashiers and stockers). In Table 2, we see several differences in employee characteristics across the six jobs we analyze-including differences in gender composition and in average wage, age, and tenure. But in none of these variables is there a commonality between baggers and meat and produce employees. However, returning to Table 1, we see that one thing these positions do have in common is a relatively small number of employees per store. The average store has 3.2 baggers, 1.1 meat wrappers, 2.1 meat cutters, and 1.6 produce clerks. By contrast, the typical store has 8.0 cashiers and 6.4 stockers. This comparison suggests that manager ethnicity matters more in departments with fewer employees.

To test this hypothesis more formally, we pool newly hired employees in all jobs and estimate versions of equation (1) that include the interaction of Mgr Hispanic with one of several variables measuring the number of coworkers in the employee's job or department. ${ }^{18}$ We find significant differences between large and small departments. Specifically, our estimates suggest that manager ethnicity affects the probability of hiring a Hispanic employee only in very small departments where the newly hired employee has either one coworker or no coworkers. ${ }^{19}$

There are good theoretical reasons that all three potential causes of differential hiring patternsdiscrimination, networks, and production complementarities — might operate with greater force in smaller departments. First, the smaller the number of employees the more difficult it is to prove that a given ethnic distribution of employment resulted from systematic bias rather than from chance. If managers in

\footnotetext{
${ }^{18}$ We examine the number of coworkers in linear form and we explore nonlinearities using dummy variables indicating various department size thresholds. In the case of meat wrappers and meat cutters, our definition of coworkers includes all meat department employees except the manager. The estimation equation includes dummy variables indicating each of the job titles. Also, because larger stores are located in cities with more Hispanics, we also control for the interaction of $M g r_{-} H_{i s p a n i c}$ with the average Hispanic share of all employees in the store.

${ }^{19}$ This finding is consistent with evidence from previous studies that discrimination and segregation are more prevalent in smaller establishments. For example, Carrington and Troske (1998) find a stronger relationship between manager and employee race in smaller establishments? And Holzer (1998) finds that smaller firms hire fewer blacks than large ones. However, we are not aware of any studies that examine whether the size of departments within a firm matters.
} 
small departments have input on hiring, they may thus feel less constrained by the need to appear unbiased, and as a result may be more likely to indulge their preferences or to use network-based recruiting strategies. Second, a manager's preference for having similar employees may be nonlinear. For example, if managers have strong preferences for having at least one employee of the same ethnicity, but weak preferences regarding the overall ethnic distribution of employees, then manager ethnicity would tend to affect hiring patterns only when the numbers are very small. Finally, in smaller departments, employees are more likely to rely on their managers (rather than on co-workers) for training and they are also more likely to interact with their managers on a regular basis. As a result, production complementarities between ethnically similar managers and employees are likely to be more important in small departments.

Because all three sources of bias could explain differential hiring in small departments, we next ask which of these explanations is more likely given what we know about how hiring decisions are made. On one hand, baggers are hired the by the store managers, and hence the findings for baggers would certainly fit with theories of discrimination or networks. Further, because the bagger position requires relatively little training or regular interaction with the store manager, production complementarities are perhaps a less likely explanation. On the other hand, company-level managers have ultimate say in hiring meat and produce workers, and so here discrimination or networks are less likely to explain why department manager ethnicity affects hiring patterns. A more likely explanation is that production complementarities are important in these departments.

Finally, we can learn more about the likely nature of these production complementarities by examining transfers between stores of experienced employees. Production complementarities may arise either because ethnic similarity facilitates training of new employees or because shared ethnicity leads to higher productivity on a regular basis. However, complementarities in training would matter only for new employees. Table 7 shows the results of regression analysis identical to that which produced the results in Table 6-except that the dependent variable is defined with respect to new transfers into the store instead of new hires. In no job position does manager ethnicity affect the probability that a new 
transfer is Hispanic. The estimates are all very close to zero and are estimated with at least as much precision as those from our hiring analysis. We can infer from this finding that in meat and produce departments, manager-employee similarity is likely to be important because it facilitates the training of new employees.

\section{Manager-Employee Ethnic Differences and Employee Separation Rates}

We examine the effect of manager-employee ethnic differences on employee separation rates by estimating a linear probability model where the dependent variable is equal to one if an individual observed in one year separated from the firm within the following year. We again exploit within-store variation in manager ethnicity to control for unobserved differences across workplaces, because it is again important to distinguish the effects of differences in manager ethnicity from unobserved workplace differences. For example, suppose that neighborhoods are segregated and that Hispanic managers tend to work at stores in Hispanic neighborhoods while white managers work in white neighborhoods. Hispanic employees who work at the stores with white managers might then have lower job attachment simply because they have longer commutes.

Equation (3) shows the general form of the estimation equations. The parameter of interest is the coefficient $\beta$ on a dummy variable (Mgr_Different_Ethnicity) that equals one if the employee's manager at time $t$ is of a different ethnicity from the employee.

(3) $\operatorname{Pr}\left(\right.$ Separated $\left._{i j t}=1\right)=\alpha+\beta M g r \_$Different_Ethnicity ${ }_{i j t}+X_{i t} \gamma+M_{j t} \eta+W_{j t} \zeta+T_{t} \delta+\mu_{j}+\varepsilon_{i j t}$. A positive value for $\beta$ would indicate that employees whose manager is a different ethnicity are more likely to separate from the firm within the following year. We control for a vector of employee characteristics $\left(X_{j t}\right)$ that includes ethnicity and gender indicators, employee age and its square, and tenure and its square; and for dummy variables indicating the ethnicity of the employee's manager at time $t\left(M_{j t}\right)$. We also control for other time-varying characteristics of the store's workforce $\left(W_{j t}\right)$, a set of year indicators $\left(T_{t}\right)$, and store fixed effects $\left(\mu_{j}\right)$. Because we typically have more than one observation per individual employee, we adjust the standard errors to account for clustering at the level of the employee.

We estimate several variations of equation (3), and we run separate regressions for each of four 
groups: baggers, cashiers, stockers, and meat and produce employees. The results are shown in Table 8 . Column (1) controls only for characteristics of the employee and his or her manager, plus the store and year fixed effects. We obtain a positive and statistically significant estimate of $\beta$ for only one groupcashiers. The estimate suggests that cashiers are 4.5 percentage points (roughly 40 percent) more likely to separate from the firm when they have an ethnically dissimilar manager. For baggers, our estimate is positive but statistically insignificant, and for stockers, and for meat and produce employees, the estimates are very close to zero. The estimates are similarly very close to zero when we estimate separate regressions for meat wrappers, meat cutters, and produce clerks, and there are no significant differences in the effect of manager-employee ethnic differences among these three job titles.

Column (2) examines whether separations are related to the fraction of all salaried managers that share the employee's ethnicity. This could be the case, for example, if the presence of same-ethnicity role models or mentors were an important determinant of job attachment. However, we find no evidence that this variable is related to separation rates.

If employees prefer working with similar others, then separation rates could also be affected by changes in the fraction of coworkers that share the employee's ethnicity. We examine this hypothesis in Column (3), which adds a variable measuring the fraction of coworkers' who are a different ethnicity from the employee. This variable is set equal to zero for employees with no coworkers, and we include a dummy variable for employees with no coworkers. We also control for the number of coworkers and for the fraction of coworkers in each ethnic group. We find significant effects of coworker dissimilarity on separations in one case only: baggers. The results suggest that having more ethnically dissimilar coworkers does increase separation rates for baggers. A 50 percentage point increase in the share of coworkers who are a different ethnicity (e.g., an increase from one out of two to two out of two coworkers) corresponds to roughly a seven percentage point (or 15 percent) increase in the probability of separation.

Columns (4) and (5) show the results from specifications that control for changes in the ethnic composition of each store's labor pool over time. Column (4) controls for the fraction of managers and 
employees in other departments who are a different ethnicity from the employee, and for the fraction of those other managers and employees who are Hispanic. Column (5) drops these variables but adds storespecific trends to the model. The estimated effect of having a dissimilar manager on cashier separation rates is robust to these last two model specifications, though the estimates become somewhat less precise. The effect of coworker dissimilarity on bagger separation rates is also robust. And finally, the estimated effects of manager-employee dissimilarity for stockers and for meat and produce employees remain very close to zero.

The analysis of separations can help us assess whether employee discrimination plays a role in the overall ethnic segregation of the workforce. Likewise, this analysis can shed some light on whether employee discrimination explains the differential hiring patterns. If employees discriminate when deciding whether to leave a job, then one might expect them also to discriminate when deciding whether to accept a job. Of course, decisions regarding separations are not always made by the employees, and unfortunately we cannot distinguish quits from dismissals. However, under the union contract, employees may be dismissed only for cause, so overall separation rates should be closely tied to quit rates.

If we assume that employee discrimination should manifest itself in higher separation rates among employees with ethnically dissimilar managers, then our results might suggest that with the possible exception of cashiers, employee discrimination is not an important source of ethnic segregation at this firm. But even if employees were discriminating, there are three reasons why manager-employee ethnic differences might not lead to higher separation rates.

First, employee discrimination could affect hiring outcomes but not separation rates if employees who would quit rather than work for an ethnically different manager simply refuse to take jobs with dissimilar managers in the first place. But in our sample many employees receive new managers at some point during their employment with the firm; hence selection at the hiring stage does not guarantee that employees with discriminatory preferences will never have an ethnically dissimilar manager. Moreover, we re-estimate our model after restricting the sample to employees who receive new managers (i.e. 
different from the ones they chose to work for), and our estimated effects of manager-employee dissimilarity remain very close to zero.

Second, employee discrimination might not affect separation rates if employees who want to stop working with their current manager have the option of transferring instead of quitting. Table 9 shows the results of regression analysis identical to that which produced Table 8 - except that the dependent variable is a dummy variable equal to one if the employee transferred to another store within the next year. While the results suggest employee discrimination may have a small effect on transfers among stockers, the estimates are not statistically significant. And for the rest of the jobs, the estimates are close to zero. Again, we also re-estimate these models using only the subsample of employees who received a new manager, and we find no significant effects of ethnic differences between manager and employee.

Finally, because our data only has information on employees who were present on December $31^{\text {st }}$ of each year, it is possible sample selection bias has affected our estimates. If employees who dislike working for dissimilar managers tend to quit after only a few months, then many of those employees will be missing from our data. In this case, estimates based on the employees we do observe will understate the effect that ethnic dissimilarity has on separation rates. ${ }^{21}$ We can assess the impact of such selection bias by asking whether the estimated effects of ethnic dissimilarity on separations are larger among employees who have been hired very recently (e.g. within three, six or nine months). We find no significant differences by employee tenure, and therefore conclude that sample selection bias is not important for our results.

Here, the weight of the evidence suggests that for all jobs except cashiers, employee discrimination probably is not an important source of segregation at our workplace. The evidence suggests it does not affect separation rates. What's more, our analysis of employees who receive new managers also suggests that employee discrimination cannot explain different hiring rates for Hispanic

\footnotetext{
${ }^{21}$ Such sample selection bias could also cause the estimates from our analysis of new hires to overstate the effects of manager ethnicity, because new hires whose ethnicity differed from the managers, having quit more quickly, would be underrepresented in our data. This is unlikely to be an issue for meat and produce employees, whose average tenure ranges from 6.5 to 9 years, but is a potential issue for baggers.
} 
employees under Hispanic and non-Hispanic managers.

Finally, we should ask why we do find some evidence that ethnic differences lead to higher separation rates for cashiers, but not other jobs. Here, it is again interesting to consider what separates cashiers from the other jobs. Returning to Tables 2 and 3, we see that while all management positions and all other non-entry level positions were occupied predominantly by men, the cashier position is occupied almost entirely by women. Further, the probability of promotion for these women was very close to zero during our sample period, and a class action lawsuit brought by several female employees against the firm in the early 1980s suggests that the employees were both aware of and resentful of this statistic. Cashiers were thus predominantly female employees with male managers who had very low expectations of ever advancing within the firm. ${ }^{22}$ Perhaps under these strained working conditions, sensitivity to ethnic differences was more of a catalyst.

\section{Conclusion}

Although it is well documented that U.S. workplaces are highly segregated by employee ethnicity, much less is known about the sources of this segregation. Using nine years of personnel records from a regional grocery chain, this study examines both the effect of manager ethnicity on hiring patterns and the effect of manager-employee ethnic differences on employee separations.

The results suggest that in our setting manager ethnicity affects the ethnic composition of employees mainly through the hiring process. For baggers, the only position over which store managers exercise direct decision-making authority, we find that manager ethnicity has a large and statistically significant impact on the rate at which Hispanic employees are hired. We also find that Hispanic employees are much more likely to be hired into the produce or meat department if the manager of that department is Hispanic, even though it is very unlikely that the department manager has any direct authority in the hiring process. Interestingly, this effect is limited to departments or positions in which there are only one or two employees; in larger departments—-stockers and cashiers-we find no

\footnotetext{
${ }^{22}$ Meat wrappers were also predominantly female and had very low promotion rates; however, meat wrappers earn 15 percent higher wages than cashiers.
} 
significant effect of manager ethnicity.

Further, we find no significant differences by manager ethnicity when examining employees who transfer in from other stores. And we find that manager-employee ethnic differences affect rates of employee separations in only one case: cashiers. This was not one of the positions where hiring biases are found, and further consideration suggests this was perhaps a special case exacerbated by strained working conditions that indeed prompted a lawsuit for gender bias.

Why does manager ethnicity affect hiring patterns? In the case of baggers, the only position for which store level managers have direct hiring authority, the most likely sources of hiring bias are tastebased discrimination by managers and the use of ethnically segregated hiring networks to recruit new employees. The results for produce and meat department employees suggest that when hiring new employees into small departments, human resource managers in the firm deliberately assign Hispanic employees to departments where they will be supervised by a Hispanic manager. This could enhance productivity to the extent that cultural or language similarity facilitates training.

It is difficult to know how well our specific results may generalize to other firms and other sectors. Our findings suggest that even within a firm, the role of manager ethnicity may vary across departments. In particular, they imply that the size of the department may influence the extent of biases in hiring. Our findings thus suggest a need for more research on hiring biases at small firms and in small departments within firms. 


\section{References}

Antonovics, Kate and Brian G. Knight. 2009. "A New Look at Racial Profiling: Evidence from the Boston Police Department." Review of Economics and Statistics 91(1): 163-175.

Aslund, Olof, Lena Hensvik and Oskar Nordstrom Skans. 2009. "Seeking Similarity: How Immigrants and Natives Manage at the Labor Market.” IZA Discussion Paper No. 4640.

Bates, Timothy. 1994. "Utilization of Minority Employees in Small Business: A Comparison of Nonminority and Black-Owned Enterprises.” Review of Black Political Economy 23: 113-121.

Becker, Gary S. 1971. The Economics of Discrimination, $2^{\text {nd }}$ edition. Chicago, IL.: The University of Chicago Press.

Carrington, William J. and Kenneth R. Troske. 1998. "Interfirm Segregation and the Black/White Wage Gap.” Journal of Labor Economics 16(2): 231-60.

Dee, Thomas S. 2005. “A Teacher Like Me: Does Race, Ethnicity or Gender Matter?” American Economic Review 95(2): 158-165.

Giuliano, Laura, David I. Levine, and Jonathan Leonard. 2009a. "Manager Race and the Race of New Hires." Journal of Labor Economics 27(4): 589-631.

Giuliano, Laura, David I. Levine, and Jonathan Leonard. 2009b. "Racial Bias in the Manager-Employee Relationship: An Analysis of Quits, Dismissals, and Promotions at a Large Retail Firm.” Journal of Human Resources, forthcoming.

Hellerstein, Judith K. and David Neumark. 2008. "Workplace Segregation in the United States: Race, Ethnicity, and Skill." The Review of Economics and Statistics 90(3): 459-477.

Holzer, Harry J. 1998. “Why Do Small Establishments Hire Fewer Blacks than Large Ones?” Journal of Human Resources 33(4): 896-908.

Kenney, Genevieve and Douglas Wissoker. 1994. "An Analysis of the Correlates of Discrimination Facing Young Hispanic Job-Seekers.” American Economic Review 84: 674-83.

Lang, Kevin. 1986. “A Language Theory of Discrimination.” Quarterly Journal of Economics 101(2): 363-82.

Ransom, M. and Oaxaca R. 2005. "Intrafirm Mobility and Sex Differences in Pay." Industrial and Labor Relations Review 58( 2): 219-237.

Stoll, Michael A., Steven Raphael, and Harry J. Holzer. 2004. "Black Job Applicants and the Hiring Officer's Race.” Industrial and Labor Relations Review 57: 267-287. 
Figure 1. Store-Level Organization

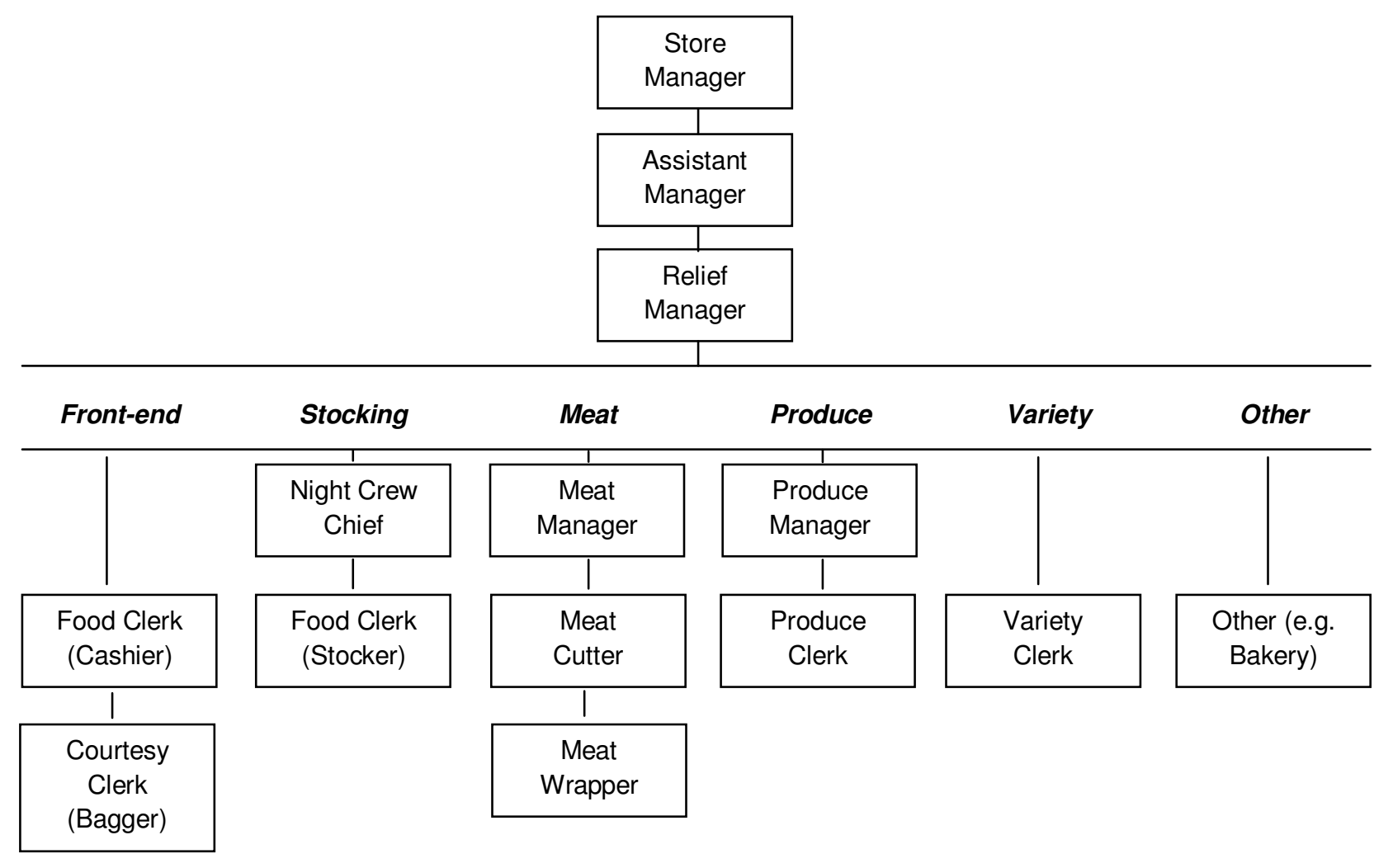


Table 1. Characteristics of Retall Stores and Workforces

\begin{tabular}{|c|c|c|c|c|}
\hline$\underline{\underline{\text { Variable }}}$ & $\underline{\text { mean }}$ & std. dev. & $\underline{\text { min. }}$ & $\underline{\underline{\max } .}$ \\
\hline number of retail employees in store & 28.8 & 8.2 & 10 & 55 \\
\hline number of baggers & 3.2 & 1.9 & 0 & 13 \\
\hline number of cashiers & 8.0 & 3.5 & 2 & 20 \\
\hline number of stockers & 6.4 & 2.6 & 1 & 15 \\
\hline number of meat wrappers & 1.1 & 0.8 & 0 & 4 \\
\hline number of meat cutters & 2.1 & 1.0 & 0 & 6 \\
\hline number of produce clerks & 1.6 & 1.0 & 0 & 6 \\
\hline \% store's retail employees who are white, non-Hispanic & $82.4 \%$ & $16.1 \%$ & $8.3 \%$ & $100 \%$ \\
\hline \% store's retail employees who are Hispanic & $14.9 \%$ & $15.1 \%$ & $0.0 \%$ & $91.7 \%$ \\
\hline$\%$ store's retail employees who are non-white, non-Hisp. & $2.7 \%$ & $3.8 \%$ & $0.0 \%$ & $28.6 \%$ \\
\hline$\%$ Hispanic of local population * & $13.4 \%$ & $15.1 \%$ & $0.6 \%$ & $71.3 \%$ \\
\hline$\%$ Foreign-born of local population** & $5.6 \%$ & $3.4 \%$ & $1.6 \%$ & $25.3 \%$ \\
\hline $\begin{array}{l}\text { \% Spanish-speakers who don’t speak English well, } \\
\text { of local adult population }{ }^{\star \star}\end{array}$ & $1.6 \%$ & $2.9 \%$ & $0.0 \%$ & $18.5 \%$ \\
\hline
\end{tabular}

Notes: Workforce size and demographic statistics based on panel of 73 stores with a total of $\mathrm{N}=532$ store-year observations; * Based on 1980 Census; for all Census tracts within one mile radius of store. For 14 stores in areas that were not tracted in 1980 Census, ZIP-code level statistic is used.

${ }_{\star \star}$ Based on 1980 Census, STF3b; ZIP-code level statistics. 


\begin{tabular}{|c|c|c|c|c|c|c|}
\hline \multirow{3}{*}{ Employee characteristics: } & \multirow[b]{2}{*}{ baggers } & \multicolumn{2}{|c|}{ food clerks: } & \multirow{2}{*}{$\begin{array}{c}\text { meat } \\
\text { wrappers }\end{array}$} & \multirow{2}{*}{$\begin{array}{c}\text { meat } \\
\text { cutters }\end{array}$} & \multirow{2}{*}{$\begin{array}{c}\text { produce } \\
\text { clerks }\end{array}$} \\
\hline & & cashiers & stockers & & & \\
\hline & & & & & & \\
\hline \% white, non-Hispanic & $80.5 \%$ & $82.1 \%$ & $82.7 \%$ & $76.6 \%$ & $74.8 \%$ & $70.7 \%$ \\
\hline \% Hispanic & $17.7 \%$ & $13.1 \%$ & $15.4 \%$ & $21.8 \%$ & $20.1 \%$ & $26.5 \%$ \\
\hline$\%$ non-white & $1.8 \%$ & $4.8 \%$ & $1.8 \%$ & $1.6 \%$ & $5.1 \%$ & $2.7 \%$ \\
\hline$\%$ female & $28.2 \%$ & $97.6 \%$ & $4.0 \%$ & $98.6 \%$ & $0.8 \%$ & $6.3 \%$ \\
\hline age & $\begin{array}{l}19.1 \\
(5.7)\end{array}$ & $\begin{array}{c}38.5 \\
(12.0)\end{array}$ & $\begin{array}{l}27.4 \\
(8.7)\end{array}$ & $\begin{array}{c}43.0 \\
(11.4)\end{array}$ & $\begin{array}{c}40.5 \\
(11.7)\end{array}$ & $\begin{array}{l}28.3 \\
(10.3)\end{array}$ \\
\hline$\%$ part-time & $98.6 \%$ & $70.1 \%$ & $59.8 \%$ & $23.4 \%$ & $8.6 \%$ & $53.5 \%$ \\
\hline tenure (years) & $\begin{array}{c}0.9 \\
(0.9)\end{array}$ & $\begin{array}{c}6.4 \\
(5.5)\end{array}$ & $\begin{array}{c}5.5 \\
(4.5)\end{array}$ & $\begin{array}{l}9.0 \\
(7.1)\end{array}$ & $\begin{array}{c}7.0 \\
(5.5)\end{array}$ & $\begin{array}{c}6.5 \\
(6.2)\end{array}$ \\
\hline wage (year-end, 1980) & $\begin{array}{l}\$ 2.92 \\
(0.26)\end{array}$ & $\begin{array}{l}\$ 7.36 \\
(1.12)\end{array}$ & $\begin{array}{l}\$ 7.27 \\
(1.19)\end{array}$ & $\begin{array}{l}\$ 8.50 \\
(0.26)\end{array}$ & $\begin{array}{l}\$ 9.41 \\
(0.43)\end{array}$ & $\begin{array}{l}\$ 7.39 \\
(1.12)\end{array}$ \\
\hline \multicolumn{7}{|l|}{ Measures of ethnic dissimilarity: } \\
\hline$\%$ whose manager is a different ethnicity/race ${ }^{a}$ & $17.2 \%$ & $18.4 \%$ & $22.0 \%$ & $31.9 \%$ & $33.5 \%$ & $32.8 \%$ \\
\hline$\%$ who are white with a non-white mgr. & $1.0 \%$ & $1.9 \%$ & $10.2 \%$ & $16.4 \%$ & $13.9 \%$ & $17.6 \%$ \\
\hline$\%$ who are Hispanic with a non-Hispanic mgr. & $14.6 \%$ & $11.7 \%$ & $10.1 \%$ & $13.9 \%$ & $14.7 \%$ & $12.4 \%$ \\
\hline $\begin{array}{l}\% \text { of salaried managers whose ethnicity/race } \\
\text { differs from the employee's }\end{array}$ & $\begin{array}{l}18.7 \% \\
(34.9)\end{array}$ & $\begin{array}{l}20.6 \% \\
(36.4)\end{array}$ & $\begin{array}{l}18.3 \% \\
(35.2)\end{array}$ & $\begin{array}{l}25.8 \% \\
(40.1)\end{array}$ & $\begin{array}{l}25.7 \% \\
(40.3)\end{array}$ & $\begin{array}{l}28.3 \% \\
(41.8)\end{array}$ \\
\hline $\begin{array}{l}\text { \% of employee's coworkers whose ethnicity/race } \\
\text { differs from the employee's c }\end{array}$ & $\begin{array}{l}21.9 \% \\
(32.4)\end{array}$ & $\begin{array}{l}27.6 \% \\
(31.0)\end{array}$ & $\begin{array}{l}22.8 \% \\
(30.0)\end{array}$ & $\begin{array}{l}32.2 \% \\
(35.8)\end{array}$ & $\begin{array}{l}31.6 \% \\
(36.1)\end{array}$ & $\begin{array}{l}21.9 \% \\
(32.4)\end{array}$ \\
\hline \multicolumn{7}{|l|}{$\begin{array}{l}\text { Measures of employment flows... } \\
\ldots \text { into jobs: }\end{array}$} \\
\hline$\%$ newly hired within past year & $68.3 \%$ & $10.0 \%$ & $8.9 \%$ & $7.5 \%$ & $8.0 \%$ & $6.8 \%$ \\
\hline$\%$ transferred from another store within past year & $0.5 \%$ & $10.1 \%$ & $12.1 \%$ & $17.1 \%$ & $21.2 \%$ & $9.6 \%$ \\
\hline$\%$ promoted from another job within past year & $0.0 \%$ & $2.3 \%$ & $5.8 \%$ & $0.0 \%$ & $1.2 \%$ & $7.1 \%$ \\
\hline \multicolumn{7}{|l|}{... out of jobs: } \\
\hline$\%$ separated from company within year & $44.5 \%$ & $10.6 \%$ & $12.2 \%$ & $16.6 \%$ & $9.4 \%$ & $11.7 \%$ \\
\hline$\%$ transferred to another store within year & $0.3 \%$ & $10.6 \%$ & $12.2 \%$ & $16.3 \%$ & $20.1 \%$ & $8.9 \%$ \\
\hline$\%$ promoted to another job within year & $25.6 \%$ & $0.6 \%$ & $7.5 \%$ & $1.9 \%$ & $5.4 \%$ & $5.1 \%$ \\
\hline Number of employee-year observations & 1717 & 4,255 & 3,410 & 563 & 1,097 & 840 \\
\hline
\end{tabular}

Notes: Standard deviations in parentheses (suppressed for dummy variables). Employment-weighted averages across store-years. " "Manager" refers to the highest-ranking salaried manager present (e.g. store manager or assistant manager) for baggers and cashiers, the night crew chief for stockers, the meat manager for meat cutters and meat wrappers, and the produce manager for produce clerk. "Salaried managers" refers to the store, assistant, and relief managers at the store where the individual is employed. " "Coworkers" refers to all employees with the same job title in the same store and year, excluding the individual. For meat wrappers and meat cutters, coworkers include all nonmanagerial meat department employees. Means based on employees who have at least one coworker. 


\begin{tabular}{lcccccc}
\hline & \multicolumn{3}{c}{ Salaried managers: } & \multicolumn{3}{c}{ Other managers: } \\
\cline { 2 - 7 } Manager characteristics: & $\begin{array}{c}\text { store } \\
\text { mgr. }\end{array}$ & asst. mgr. & $\begin{array}{c}\text { relief } \\
\text { mgr. }\end{array}$ & $\begin{array}{c}\text { night crew } \\
\text { chief }\end{array}$ & $\begin{array}{c}\text { meat } \\
\text { mgr. }\end{array}$ & $\begin{array}{c}\text { produce } \\
\text { mgr. }\end{array}$ \\
\cline { 2 - 7 } \% white, non-Hispanic & & & & & & \\
\% Hispanic & $97.0 \%$ & $92.5 \%$ & $87.8 \%$ & $81.4 \%$ & $79.6 \%$ & $69.6 \%$ \\
\% non-white & $2.5 \%$ & $6.5 \%$ & $10.7 \%$ & $17.7 \%$ & $18.5 \%$ & $29.6 \%$ \\
\% female & $0.4 \%$ & $1.1 \%$ & $1.5 \%$ & $0.1 \%$ & $1.8 \%$ & $0.8 \%$ \\
age & $0.2 \%$ & $2.5 \%$ & $2.5 \%$ & $6.3 \%$ & $0.2 \%$ & $0.0 \%$ \\
& 39.0 & 33.6 & 30.0 & 29.2 & 41.6 & 37.0 \\
tenure (years) & $(9.4)$ & $(9.3)$ & $(9.2)$ & $(8.8)$ & $(9.4)$ & $(9.3)$ \\
& 15.6 & 10.4 & 6.9 & 5.9 & 12.3 & 14.7 \\
wage (year-end, 1980) & $(7.7)$ & $(6.3)$ & $(5.0)$ & $(3.8)$ & $(6.8)$ & $(8.3)$ \\
Annual Earnings (year-end, 1980) & $\mathrm{n} / \mathrm{a}$ & $\mathrm{n} / \mathrm{a}$ & $\mathrm{n} / \mathrm{a}$ & $\$ 8.21$ & $\$ 9.80$ & $\$ 8.41$ \\
& & & & $(0.39)$ & $(0.21)$ & $(0.34)$ \\
\% Turnover within one year & $\$ 28,611$ & $\$ 23,880$ & $\$ 21,692$ & $\$ 17,370$ & $\$ 20,947$ & $\$ 25,720$ \\
Number of store-year observations & $(4,718)$ & $(810)$ & $(1,380)$ & $(3,216)$ & $(1,863)$ & $(1,370)$ \\
\hline
\end{tabular}

TABle 4. Employee EthNic Composition by Manager Ethnicity

\begin{tabular}{lccc}
\hline \hline & \multicolumn{3}{c}{ Manager's ethnicity: } \\
$\begin{array}{l}\text { Store manager } \\
\text { \% Hispanic of baggers }\end{array}$ & $\begin{array}{c}\text { white, } \\
\text { non-Hisp. }\end{array}$ & difference \\
$\begin{array}{l}\text { \% Hispanic of cashiers } \\
\text { Night crew chief }\end{array}$ & 43.8 & 15.2 & 67.6 \\
$\begin{array}{l}\text { \% Hispanic of stockers } \\
\text { Meat dept. manager }\end{array}$ & 34.9 & 12.1 & 31.4 \\
$\begin{array}{l}\text { \% Hispanic of meat wrappers } \\
\text { \% Hispanic of meat cutters }\end{array}$ & 35.8 & 11.7 & 23.2 \\
$\begin{array}{l}\text { Produce manager } \\
\text { \% Hispanic of produce clerks }\end{array}$ & 27.7 & 17.2 & 18.4 \\
$\begin{array}{l}\text { All managers } \\
\text { \% Hispanic of employees }\end{array}$ & 44.7 & 18.0 & 26.6 \\
\hline
\end{tabular}


Table 5. Cross-Section Analysis of WorkPlace Segregation in 1980

\begin{tabular}{|c|c|c|}
\hline Baggers & (1) & (2) \\
\hline Manager is Hispanic & $\begin{array}{l}\mathbf{0 . 8 1 3}^{\text {** }} \\
(0.037)\end{array}$ & $\begin{array}{c}\mathbf{0 . 2 1 5} \\
(0.155)\end{array}$ \\
\hline$\%$ Hispanic within 1 mile & & $\begin{array}{l}1.112^{* *} \\
(0.248)\end{array}$ \\
\hline Observations & 333 & 333 \\
\hline R-squared & 0.15 & 0.30 \\
\hline Cashiers & $\underline{(1)}$ & (2) \\
\hline Manager is Hispanic & $\begin{array}{l}\mathbf{0 . 3 5 9}^{\star *} \\
(0.082)\end{array}$ & $\begin{array}{c}\mathbf{0 . 0 2 3} \\
(0.133)\end{array}$ \\
\hline$\%$ Hispanic within 1 mile & & $\begin{array}{l}0.618^{* *} \\
(0.160)\end{array}$ \\
\hline Observations & 618 & 618 \\
\hline R-squared & 0.03 & 0.10 \\
\hline Stockers & (1) & $\underline{(2)}$ \\
\hline Manager is Hispanic & $\begin{array}{l}\mathbf{0 . 2 2 7}^{\star} \\
(0.113)\end{array}$ & $\begin{array}{c}\mathbf{0 . 0 8 4} \\
(0.052)\end{array}$ \\
\hline$\%$ Hispanic within 1 mile & & $\begin{array}{l}0.895^{\star *} \\
(0.249)\end{array}$ \\
\hline Observations & 411 & 411 \\
\hline R-squared & 0.06 & 0.19 \\
\hline Meat \& Produce Employees & (1) & (2) \\
\hline Manager is Hispanic & $\begin{array}{l}\mathbf{0 . 2 0 8}^{\star * *} \\
(0.057)\end{array}$ & $\begin{array}{l}\mathbf{0 . 1 0 9 ^ { \ddagger }} \\
(0.064)\end{array}$ \\
\hline$\%$ Hispanic within 1 mile & & $\begin{array}{l}0.830^{* *} \\
(0.263)\end{array}$ \\
\hline Observations & 344 & 344 \\
\hline R-squared & 0.05 & 0.14 \\
\hline All Employees & (1) & (2) \\
\hline Manager is Hispanic & $\begin{array}{c}\mathbf{0 . 2 7 6}^{\star *} \\
(0.095)\end{array}$ & $\begin{array}{l}\mathbf{0 . 1 0 1 ^ { * }} \\
(0.040)\end{array}$ \\
\hline$\%$ Hispanic within 1 mile & & $\begin{array}{l}0.836^{* *} \\
(0.103)\end{array}$ \\
\hline Observations & 1706 & 1706 \\
\hline R-squared & 0.06 & 0.18 \\
\hline
\end{tabular}

R-squared

0.06

Notes: Entries are estimates from linear probability models in which dependent variable $=1$ if an employee is Hispanic and 0 otherwise. Estimation sample includes all employees present either at the end of 1980 or the end of 1981. Parentheses contain robust standard errors adjusted for clustering on store. The regressions for meat and produce employees control for dummy variables indicating whether the employee is a meat wrapper, meat cutter or produce clerk. The regressions that pool all employees control for a complete set of job title indicators. All regressions also control for a dummy variable indicating whether the manager is both non-white and non-Hispanic. ${ }^{* *}$ Significant at $1 \%,{ }^{*}$ significant at $5 \%,{ }^{\ddagger}$ significant at $10 \%$. 
Table 6. Probability that a New Hire is Hispanic as a Function of the Manager's Ethicity

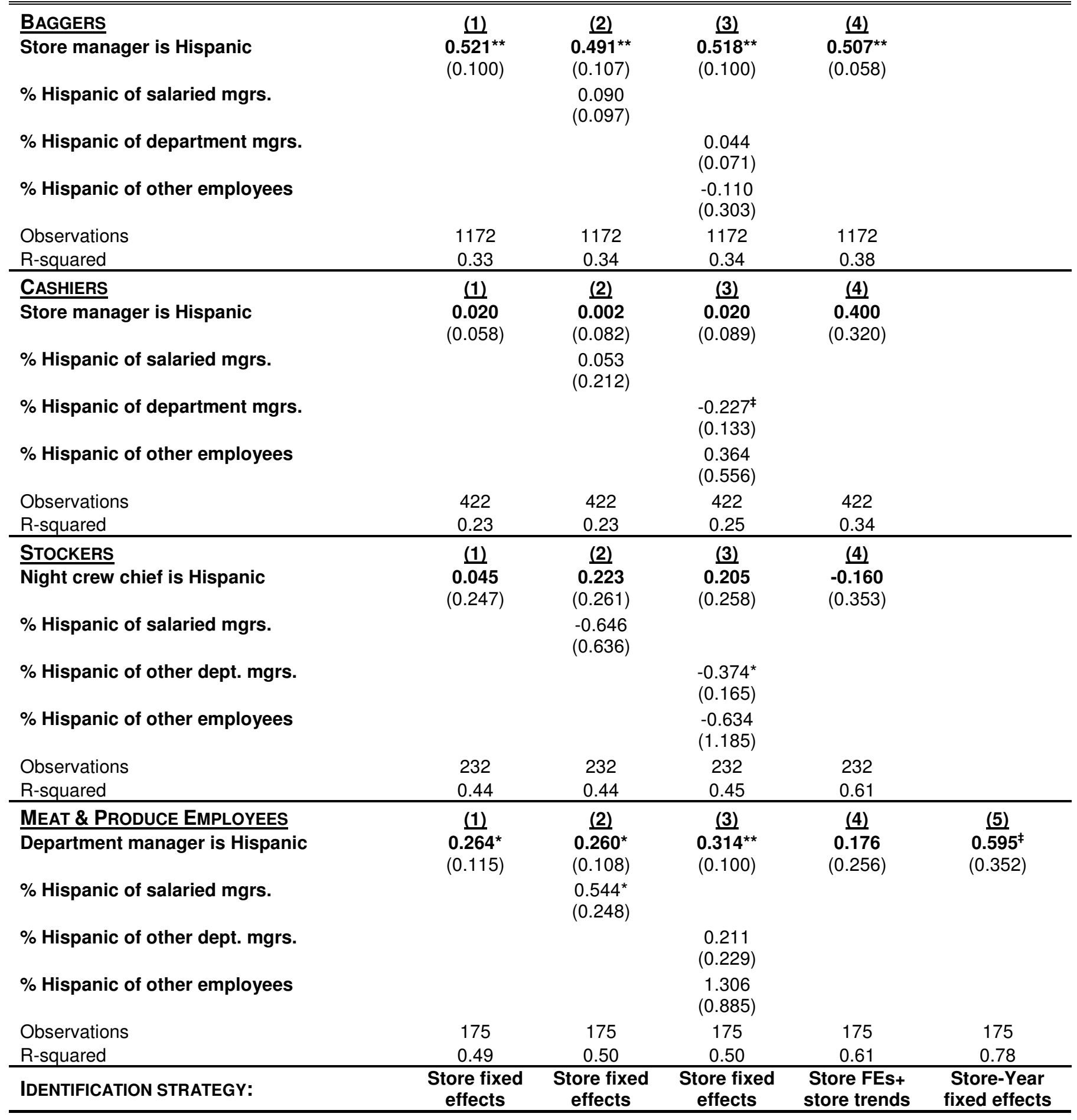

Notes: Estimates from linear probability models in which dependent variable $=1$ if new hire is Hispanic and 0 otherwise. Estimation sample includes all new hires made between 1976-1984. Robust standard errors in parenthesis, adjusted for clustering on store.

${ }^{* *}$ significant at $1 \%,{ }^{*}$ significant at $5 \%,{ }^{\ddagger}$ significant at $10 \%$. Additional controls include: a dummy variable for non-white managers (the omitted category is white non-Hispanic); a dummy for missing store managers; the number of salaried managers present; and dummy variables for eight out of nine years. Columns (2) controls for the fraction of salaried managers who are non-white. The regressions based on meat and produce employees include dummy variables indicating the job title (meat wrapper, meat cutter or produce clerk). 
Table 7. Probability that a New Transfer is Hispanic as a Function of Manager's Ethnicity

\begin{tabular}{|c|c|c|c|c|c|}
\hline$\frac{\text { CASHIERS }}{\text { Store manager is Hispanic }}$ & $\begin{array}{c}-0.066 \\
(0.105)\end{array}$ & $\begin{array}{c}\frac{(2)}{-0.170} \\
(0.169)\end{array}$ & $\begin{array}{c}\frac{(3)}{-0.065} \\
(0.154)\end{array}$ & $\begin{array}{c}\frac{(4)}{-0.455^{\star *}} \\
(0.154)\end{array}$ & \\
\hline$\%$ Hispanic of salaried mgrs. & & $\begin{array}{c}0.227 \\
(0.296)\end{array}$ & & & \\
\hline$\%$ Hispanic of department mgrs. & & & $\begin{array}{l}-0.118 \\
(0.118)\end{array}$ & & \\
\hline$\%$ Hispanic of other employees & & & $\begin{array}{c}0.111 \\
(0.772)\end{array}$ & & \\
\hline Observations & 432 & 432 & 432 & 432 & \\
\hline R-squared & 0.16 & 0.17 & 0.17 & 0.26 & \\
\hline STOCKERS & (1) & (2) & (3) & (4) & \\
\hline Night crew chief is Hispanic & $\begin{array}{l}-0.002 \\
(0.096)\end{array}$ & $\begin{array}{l}-0.005 \\
(0.097)\end{array}$ & $\begin{array}{l}-0.026 \\
(0.108)\end{array}$ & $\begin{array}{c}\mathbf{0 . 0 1 7} \\
(0.204)\end{array}$ & \\
\hline$\%$ Hispanic of salaried mgrs. & & $\begin{array}{l}-0.012 \\
(0.232)\end{array}$ & & & \\
\hline$\%$ Hispanic of other dept. mgrs. & & & $\begin{array}{l}-0.194^{\ddagger} \\
(0.097)\end{array}$ & & \\
\hline$\%$ Hispanic of other employees & & & $\begin{array}{c}0.697 \\
(0.577)\end{array}$ & & \\
\hline Observations & 358 & 358 & 358 & 358 & \\
\hline R-squared & 0.30 & 0.30 & 0.31 & 0.43 & \\
\hline MEAT \& PRODUCE EMPLOYEES & (1) & (2) & (3) & (4) & (5) \\
\hline Department manager is Hispanic & $\begin{array}{l}-0.042 \\
(0.081)\end{array}$ & $\begin{array}{l}-0.033 \\
(0.078)\end{array}$ & $\begin{array}{l}-0.055 \\
(0.079)\end{array}$ & $\begin{array}{c}\mathbf{0 . 0 4 2} \\
(0.115)\end{array}$ & $\begin{array}{l}\mathbf{0 . 1 8 8} \\
(0.315)\end{array}$ \\
\hline$\%$ Hispanic of salaried mgrs. & & $\begin{array}{l}-0.588^{\star *} \\
(0.218)\end{array}$ & & & \\
\hline$\%$ Hispanic of other dept. mgrs. & & & $\begin{array}{l}-0.235^{*} \\
(0.112)\end{array}$ & & \\
\hline$\%$ Hispanic of other employees & & & $\begin{array}{l}-0.179 \\
(0.589)\end{array}$ & & \\
\hline Observations & 407 & 407 & 406 & 407 & 407 \\
\hline R-squared & 0.22 & 0.23 & 0.23 & 0.32 & 0.58 \\
\hline IDENTIFICATION STRATEGY: & $\begin{array}{l}\text { Store fixed } \\
\text { effects }\end{array}$ & $\begin{array}{l}\text { Store fixed } \\
\text { effects }\end{array}$ & $\begin{array}{c}\text { Store fixed } \\
\text { effects }\end{array}$ & $\begin{array}{l}\text { Store FEs+ } \\
\text { store trends }\end{array}$ & $\begin{array}{l}\text { Store-Year } \\
\text { fixed effects }\end{array}$ \\
\hline
\end{tabular}

Notes: Estimates from linear probability models in which dependent variable $=1$ if an employee who has newly transferred from another store is Hispanic and 0 otherwise. Estimation sample includes all new transfers made between 1977-1984, excluding promotions. See also notes from Table 6. 
Table 8. Probability of Separation as a Function of Ethnic Dissimilarity from Manager

\begin{tabular}{|c|c|c|c|c|c|}
\hline BAGGERS & (1) & (2) & (3) & (4) & (5) \\
\hline 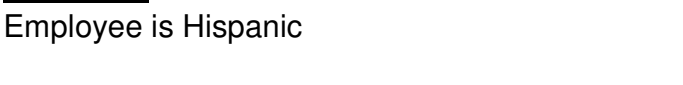 & $\begin{array}{l}-0.203 \\
(0.128)\end{array}$ & $\begin{array}{l}-0.198 \\
(0.133)\end{array}$ & $\begin{array}{l}-0.200 \\
(0.136)\end{array}$ & $\begin{array}{l}-0.199 \\
(0.149)\end{array}$ & $\begin{array}{l}-0.138 \\
(0.130)\end{array}$ \\
\hline Store manager is Hispanic & $\begin{array}{l}-0.072 \\
(0.158)\end{array}$ & $\begin{array}{l}-0.070 \\
(0.188)\end{array}$ & $\begin{array}{l}-0.060 \\
(0.166)\end{array}$ & $\begin{array}{l}-0.084 \\
(0.170)\end{array}$ & $\begin{array}{c}0.206 \\
(0.179)\end{array}$ \\
\hline Store manager is a different ethnicity & $\begin{array}{c}\mathbf{0 . 1 4 1} \\
(0.128)\end{array}$ & $\begin{array}{l}-0.060 \\
(0.168)\end{array}$ & $\begin{array}{c}0.088 \\
(0.138)\end{array}$ & $\begin{array}{c}0.103 \\
(0.142)\end{array}$ & $\begin{array}{c}\mathbf{0 . 0 1 9} \\
(0.130)\end{array}$ \\
\hline$\%$ salaried managers whose ethnicity differs & & $\begin{array}{c}0.230^{\ddagger} \\
(0.118)\end{array}$ & & & \\
\hline$\%$ coworkers whose ethnicity differs & & & $\begin{array}{l}\mathbf{0 . 1 2 9}^{*} \\
(0.061)\end{array}$ & $\begin{array}{l}\mathbf{0 . 1 5 3}^{*} \\
(0.062)\end{array}$ & $\begin{array}{l}\text { 0.150* } \\
(0.065)\end{array}$ \\
\hline$\%$ other dept. managers whose ethnicity differs & & & & $\begin{array}{l}-0.033 \\
(0.073)\end{array}$ & \\
\hline$\%$ other employees whose ethnicity differs & & & & $\begin{array}{l}-0.024 \\
(0.179)\end{array}$ & \\
\hline Observations & 1530 & 1528 & 1530 & 1530 & 1530 \\
\hline R-squared & 0.14 & 0.14 & 0.14 & 0.15 & 0.18 \\
\hline CASHIERS & (1) & (2) & $\underline{(3)}$ & $(4)$ & (5) \\
\hline 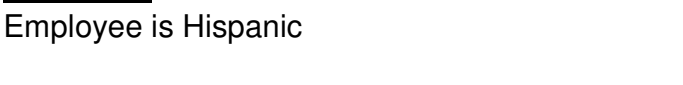 & $\begin{array}{l}-0.063^{*} \\
(0.025)\end{array}$ & $\begin{array}{c}-0.065^{\star *} \\
(0.025)\end{array}$ & $\begin{array}{l}-0.053+ \\
(0.028)\end{array}$ & $\begin{array}{l}-0.067+ \\
(0.035)\end{array}$ & $\begin{array}{l}-0.067^{*} \\
(0.031)\end{array}$ \\
\hline Store manager is Hispanic & $\begin{array}{l}-0.035 \\
(0.061)\end{array}$ & $\begin{array}{l}-0.052 \\
(0.068)\end{array}$ & $\begin{array}{l}-0.027 \\
(0.062)\end{array}$ & $\begin{array}{l}-0.037 \\
(0.062)\end{array}$ & $\begin{array}{l}-0.054 \\
(0.076)\end{array}$ \\
\hline Store manager is a different ethnicity & $\begin{array}{l}\mathbf{0 . 0 4 5}^{*} \\
(0.022)\end{array}$ & $\begin{array}{c}\mathbf{0 . 0 5 2} \\
(0.051)\end{array}$ & $\begin{array}{l}\mathbf{0 . 0 4 8 ^ { \ddagger }} \\
(0.025)\end{array}$ & $\begin{array}{c}0.044 \\
(0.034)\end{array}$ & $\begin{array}{l}\mathbf{0 . 0 4 6 ^ { \ddagger }} \\
(0.027)\end{array}$ \\
\hline$\%$ salaried managers whose ethnicity differs & & $\begin{array}{l}-0.006 \\
(0.051)\end{array}$ & & & \\
\hline$\%$ coworkers whose ethnicity differs & & & $\begin{array}{l}-0.018 \\
(0.038)\end{array}$ & $\begin{array}{l}-0.021 \\
(0.041)\end{array}$ & $\begin{array}{l}-0.003 \\
(0.042)\end{array}$ \\
\hline$\%$ other dept. managers whose ethnicity differs & & & & $\begin{array}{l}-0.029 \\
(0.031)\end{array}$ & \\
\hline$\%$ other employees whose ethnicity differs & & & & $\begin{array}{c}0.044 \\
(0.084)\end{array}$ & \\
\hline Observations & 3736 & 3732 & 3736 & 3736 & 3736 \\
\hline R-squared & 0.07 & 0.07 & 0.07 & 0.07 & 0.09 \\
\hline STOCKERS & (1) & (2) & (3) & (4) & (5) \\
\hline Employee is Hispanic & $\begin{array}{l}-0.020 \\
(0.027)\end{array}$ & $\begin{array}{l}-0.001 \\
(0.047)\end{array}$ & $\begin{array}{c}0 . \overline{015} \\
(0.035)\end{array}$ & $\begin{array}{l}-0.083 \\
(0.067)\end{array}$ & $\begin{array}{l}-0.006 \\
(0.037)\end{array}$ \\
\hline Night crew chief is Hispanic & $\begin{array}{c}0.057 \\
(0.041)\end{array}$ & $\begin{array}{c}0.059 \\
(0.041)\end{array}$ & $\begin{array}{c}0.060 \\
(0.041)\end{array}$ & $\begin{array}{c}0.068 \\
(0.042)\end{array}$ & $\begin{array}{c}0.058 \\
(0.046)\end{array}$ \\
\hline Night crew chief is a different ethnicity & $\begin{array}{l}-0.015 \\
(0.027)\end{array}$ & $\begin{array}{l}-0.013 \\
(0.027)\end{array}$ & $\begin{array}{l}-0.008 \\
(0.027)\end{array}$ & $\begin{array}{l}-0.019 \\
(0.027)\end{array}$ & $\begin{array}{l}-0.003 \\
(0.027)\end{array}$ \\
\hline$\%$ salaried managers whose ethnicity differs & & $\begin{array}{l}-0.024 \\
(0.051)\end{array}$ & & & \\
\hline$\%$ coworkers whose ethnicity differs & & & $\begin{array}{l}-0.082^{\ddagger} \\
(0.047)\end{array}$ & $\begin{array}{l}-0.123^{\star} \\
(0.055)\end{array}$ & $\begin{array}{l}-0.047 \\
(0.052)\end{array}$ \\
\hline$\%$ other dept. managers whose ethnicity differs & & & & $\begin{array}{l}-0.014 \\
(0.035)\end{array}$ & \\
\hline$\%$ other employees whose ethnicity differs & & & & $\begin{array}{l}0.192^{\ddagger} \\
(0.116)\end{array}$ & \\
\hline Observations & 2254 & 2254 & 2254 & 2254 & 2254 \\
\hline R-squared & 0.06 & 0.06 & 0.06 & 0.06 & 0.09 \\
\hline
\end{tabular}


TABLE 8, CONTINUED.

\begin{tabular}{|c|c|c|c|c|c|}
\hline MEAT \& PRODUCE EMPLOYEES & (1) & (2) & (3) & (4) & (5) \\
\hline Employee is Hispanic & $\begin{array}{l}-0.040^{\ddagger} \\
(0.022)\end{array}$ & $\begin{array}{l}-0.106^{\ddagger} \\
(0.055)\end{array}$ & $\begin{array}{l}-0.055^{\star} \\
(0.025)\end{array}$ & $\begin{array}{l}-0.109 \\
(0.076)\end{array}$ & $\begin{array}{l}-0.054^{*} \\
(0.024)\end{array}$ \\
\hline Department manager is Hispanic & $\begin{array}{l}-0.016 \\
(0.020)\end{array}$ & $\begin{array}{l}-0.015 \\
(0.020)\end{array}$ & $\begin{array}{l}-0.012 \\
(0.020)\end{array}$ & $\begin{array}{c}0.008 \\
(0.022)\end{array}$ & $\begin{array}{l}-0.043^{\ddagger} \\
(0.023)\end{array}$ \\
\hline Department manager is a different ethnicity & $\begin{array}{c}0.005 \\
(0.018)\end{array}$ & $\begin{array}{c}\mathbf{0 . 0 0 1} \\
(0.018)\end{array}$ & $\begin{array}{l}-0.001 \\
(0.018)\end{array}$ & $\begin{array}{c}-0.011 \\
(0.018)\end{array}$ & $\begin{array}{l}-0.005 \\
(0.018)\end{array}$ \\
\hline$\%$ salaried managers whose ethnicity differs & & $\begin{array}{c}\mathbf{0 . 0 7 9} \\
(0.057)\end{array}$ & & & \\
\hline$\%$ coworkers whose ethnicity differs & & & $\begin{array}{c}\mathbf{0 . 0 4 5} \\
(0.028)\end{array}$ & $\begin{array}{c}\mathbf{0 . 0 2 8} \\
(0.029)\end{array}$ & $\begin{array}{c}\mathbf{0 . 0 4 2} \\
(0.028)\end{array}$ \\
\hline$\%$ other dept. managers whose ethnicity differs & & & & $\begin{array}{c}0.024 \\
(0.027)\end{array}$ & \\
\hline$\%$ other employees whose ethnicity differs & & & & $\begin{array}{c}0.078 \\
(0.108)\end{array}$ & \\
\hline Observations & 2201 & 2198 & 2201 & 2098 & 2201 \\
\hline R-squared & 0.08 & 0.08 & 0.08 & 0.09 & 0.12 \\
\hline IDENTIFICATION STRATEGY: & $\begin{array}{l}\text { Store fixed } \\
\text { effects }\end{array}$ & $\begin{array}{l}\text { Store fixed } \\
\text { effects }\end{array}$ & $\begin{array}{l}\text { Store fixed } \\
\text { effects }\end{array}$ & $\begin{array}{c}\text { store FEs + } \\
\text { \%Hispanic } \\
\text { of others in } \\
\text { store }\end{array}$ & $\begin{array}{c}\text { store FEs + } \\
\text { Store- } \\
\text { specific } \\
\text { trends }\end{array}$ \\
\hline
\end{tabular}

Notes: Estimates from linear probability models in which dependent variable $=1$ if the employment with the company was terminated within the year. Estimation sample includes all employees present on Dec. $31^{\text {st }}$ for each year from 1976-1984, excluding employees in stores than closed the following year. Additional controls include: a dummy variable equal to one if the employee is non-white (the omitted employee ethnicity category is white non-Hispanic); a dummy variable indicating employee gender; employee age and its square; employee tenure and its square; a dummy variable equal to one if the manager is non-white (the omitted manager ethnicity category is white non-Hispanic); the number of salaried managers present; a dummy equal to one if the highest-ranking manager is the assistant mgr.; a dummy equal to one if the highestranking manager is relief manager; dummy variables for eight our of nine years. Column (3) control for the fraction of salaried managers who are Hispanic and the fraction non-white. Columns (4), (5), and (6) control for the fraction of coworkers who are Hispanic and the fraction non-white; the number of coworkers; and a dummy variable equal to one if the employee has no coworkers. (If the employee has no coworkers, then the fraction of each ethnicity and the fraction whose ethnicity differs are all set equal to zero.) Column (5) also controls for the fraction Hispanic and the fraction non-white of other department managers and of other employees. The regressions based on meat and produce employees also include dummy variables indicating the employee's current job title (meat wrapper, meat cutter, or produce clerk). Robust standard errors (in parenthesis) are adjusted for clustering on employee. ${ }^{* *}$ significant at $1 \%,{ }^{*}$ significant at $5 \%,{ }^{\ddagger}$ significant at $10 \%$. 
Table 9. Probability of Transfer OUt as a Function of Ethnic Dissimilarity from Manager

\begin{tabular}{|c|c|c|c|c|c|}
\hline BAGGERS & (1) & (2) & (3) & (4) & (5) \\
\hline Employee is Hispanic & $\begin{array}{l}-0.005 \\
(0.005)\end{array}$ & $\begin{array}{l}-0.005 \\
(0.006)\end{array}$ & $\begin{array}{l}-0.006 \\
(0.006)\end{array}$ & $\begin{array}{l}-0.003 \\
(0.007)\end{array}$ & $\begin{array}{l}-0.005 \\
(0.006)\end{array}$ \\
\hline Department manager is Hispanic & $\begin{array}{l}-0.000 \\
(0.007)\end{array}$ & $\begin{array}{c}0.014 \\
(0.014)\end{array}$ & $\begin{array}{c}0.010 \\
(0.009)\end{array}$ & $\begin{array}{c}0.019 \\
(0.013)\end{array}$ & $\begin{array}{c}0.019 \\
(0.017)\end{array}$ \\
\hline Department manager is a different ethnicity & $\begin{array}{l}-0.004 \\
(0.004)\end{array}$ & $\begin{array}{l}-0.000 \\
(0.010)\end{array}$ & $\begin{array}{l}-0.013^{\ddagger} \\
(0.008)\end{array}$ & $\begin{array}{l}-0.007 \\
(0.019)\end{array}$ & $\begin{array}{l}-0.014 \\
(0.009)\end{array}$ \\
\hline$\%$ salaried managers whose ethnicity differs & & $\begin{array}{l}-0.003 \\
(0.011)\end{array}$ & & & \\
\hline$\%$ coworkers whose ethnicity differs & & & $\begin{array}{c}\mathbf{0 . 0 2 0} \\
(0.012)\end{array}$ & $\begin{array}{l}\mathbf{0 . 0 2 1}^{\neq} \\
(0.012)\end{array}$ & $\begin{array}{c}\mathbf{0 . 0 2 4} \\
(0.015)\end{array}$ \\
\hline$\%$ other dept. managers whose ethnicity differs & & & & $\begin{array}{c}0.009 \\
(0.008)\end{array}$ & \\
\hline$\%$ other employees whose ethnicity differs & & & & $\begin{array}{l}-0.022 \\
(0.046)\end{array}$ & \\
\hline Observations & 840 & 839 & 840 & 840 & 840 \\
\hline R-squared & 0.12 & 0.12 & 0.13 & 0.13 & 0.14 \\
\hline$\underline{\text { CASHIERS }}$ & $\underline{(2)}$ & $\underline{(3)}$ & $\underline{(4)}$ & $\underline{(5)}$ & $\underline{(6)}$ \\
\hline Employee is Hispanic & $\begin{array}{l}-0.011 \\
(0.032)\end{array}$ & $\begin{array}{l}-0.002 \\
(0.032)\end{array}$ & $\begin{array}{l}-0.032 \\
(0.035)\end{array}$ & $\begin{array}{l}-0.061 \\
(0.038)\end{array}$ & $\begin{array}{l}-0.006 \\
(0.033)\end{array}$ \\
\hline Department manager is Hispanic & $\begin{array}{l}0.126^{*} \\
(0.061)\end{array}$ & $\begin{array}{l}0.153^{*} \\
(0.061)\end{array}$ & $\begin{array}{l}0.151^{*} \\
(0.060)\end{array}$ & $\begin{array}{l}0.168^{* *} \\
(0.063)\end{array}$ & $\begin{array}{l}0.151^{\ddagger} \\
(0.078)\end{array}$ \\
\hline Department manager is a different ethnicity & $\begin{array}{c}\mathbf{0 . 0 0 8} \\
(0.030)\end{array}$ & $\begin{array}{l}-0.052 \\
(0.047)\end{array}$ & $\begin{array}{l}-0.017 \\
(0.037)\end{array}$ & $\begin{array}{l}-0.041 \\
(0.043)\end{array}$ & $\begin{array}{l}-0.030 \\
(0.040)\end{array}$ \\
\hline$\%$ salaried managers whose ethnicity differs & & $\begin{array}{c}\mathbf{0 . 0 6 1} \\
(0.045)\end{array}$ & & & \\
\hline$\%$ coworkers whose ethnicity differs & & & $\begin{array}{c}\mathbf{0 . 0 7 3} \\
(0.047)\end{array}$ & $\begin{array}{c}\mathbf{0 . 0 5 4} \\
(0.053)\end{array}$ & $\begin{array}{l}\mathbf{0 . 0 8 6 ^ { \ddagger }} \\
(0.051)\end{array}$ \\
\hline$\%$ other dept. managers whose ethnicity differs & & & & $\begin{array}{l}-0.042 \\
(0.035)\end{array}$ & \\
\hline$\%$ other employees whose ethnicity differs & & & & $\begin{array}{c}0.123 \\
(0.100)\end{array}$ & \\
\hline Observations & 3339 & 3335 & 3339 & 3339 & 3339 \\
\hline R-squared & 0.09 & 0.09 & 0.09 & 0.09 & 0.11 \\
\hline$\underline{\text { STOCKERS }}$ & (2) & (3) & $(4)$ & $\underline{(5)}$ & (6) \\
\hline Employee is Hispanic & $\begin{array}{l}-0.031 \\
(0.025)\end{array}$ & $\begin{array}{c}0 . \overline{024} \\
(0.044)\end{array}$ & $\begin{array}{l}-0.032 \\
(0.031)\end{array}$ & $\begin{array}{l}-0.049 \\
(0.060)\end{array}$ & $\begin{array}{l}-0.038 \\
(0.034)\end{array}$ \\
\hline Department manager is Hispanic & $\begin{array}{c}0.037 \\
(0.046)\end{array}$ & $\begin{array}{c}0.034 \\
(0.047)\end{array}$ & $\begin{array}{c}0.038 \\
(0.047)\end{array}$ & $\begin{array}{c}0.049 \\
(0.051)\end{array}$ & $\begin{array}{c}0.044 \\
(0.052)\end{array}$ \\
\hline Department manager is a different ethnicity & $\begin{array}{c}\mathbf{0 . 0 3 4} \\
(0.026)\end{array}$ & $\begin{array}{c}\mathbf{0 . 0 4 0} \\
(0.027)\end{array}$ & $\begin{array}{c}\mathbf{0 . 0 3 8} \\
(0.027)\end{array}$ & $\begin{array}{c}\mathbf{0 . 0 3 5} \\
(0.029)\end{array}$ & $\begin{array}{c}\mathbf{0 . 0 3 8} \\
(0.028)\end{array}$ \\
\hline$\%$ salaried managers whose ethnicity differs & & $\begin{array}{l}-0.069 \\
(0.049)\end{array}$ & & & \\
\hline$\%$ coworkers whose ethnicity differs & & & $\begin{array}{l}-0.011 \\
(0.052)\end{array}$ & $\begin{array}{l}-0.005 \\
(0.062)\end{array}$ & $\begin{array}{l}-0.020 \\
(0.059)\end{array}$ \\
\hline$\%$ other dept. managers whose ethnicity differs & & & & $\begin{array}{l}-0.048 \\
(0.038)\end{array}$ & \\
\hline$\%$ other employees whose ethnicity differs & & & & $\begin{array}{c}0.050 \\
(0.112)\end{array}$ & \\
\hline Observations & 1962 & 1962 & 1962 & 1962 & 1962 \\
\hline R-squared & 0.10 & 0.10 & 0.10 & 0.10 & 0.14 \\
\hline IDENTIFICATION STRATEGY: & $\begin{array}{l}\text { Store fixed } \\
\text { effects }\end{array}$ & $\begin{array}{l}\text { Store fixed } \\
\text { effects }\end{array}$ & $\begin{array}{l}\text { Store fixed } \\
\text { effects }\end{array}$ & $\begin{array}{c}\text { store FEs + } \\
\text { \%Hispanic } \\
\text { of others } \\
\text { in store }\end{array}$ & $\begin{array}{c}\text { store FEs + } \\
\text { Store- } \\
\text { specific } \\
\text { trends }\end{array}$ \\
\hline
\end{tabular}


TABLE 9, CONTINUED.

\begin{tabular}{|c|c|c|c|c|c|}
\hline MEAT \& PRODUCE EMPLOYEES & (1) & (2) & (3) & (4) & (5) \\
\hline Employee is Hispanic & $\begin{array}{c}0 . \overline{036} \\
(0.022)\end{array}$ & $\begin{array}{c}0 . \overline{032} \\
(0.044)\end{array}$ & $\begin{array}{c}0 . \overline{034} \\
(0.024)\end{array}$ & $\begin{array}{c}0 . \overline{010} \\
(0.064)\end{array}$ & $\begin{array}{c}0 . \overline{032} \\
(0.025)\end{array}$ \\
\hline Department manager is Hispanic & $\begin{array}{l}-0.024 \\
(0.024)\end{array}$ & $\begin{array}{l}-0.021 \\
(0.024)\end{array}$ & $\begin{array}{l}-0.024 \\
(0.024)\end{array}$ & $\begin{array}{l}-0.010 \\
(0.025)\end{array}$ & $\begin{array}{l}-0.020 \\
(0.027)\end{array}$ \\
\hline Department manager is a different ethnicity & $\begin{array}{c}\mathbf{0 . 0 0 7} \\
(0.021)\end{array}$ & $\begin{array}{c}\mathbf{0 . 0 0 8} \\
(0.021)\end{array}$ & $\begin{array}{c}\mathbf{0 . 0 0 8} \\
(0.021)\end{array}$ & $\begin{array}{c}\mathbf{0 . 0 1 2} \\
(0.022)\end{array}$ & $\begin{array}{c}\mathbf{0 . 0 1 0} \\
(0.021)\end{array}$ \\
\hline$\%$ salaried managers whose ethnicity differs & & $\begin{array}{c}\mathbf{0 . 0 0 5} \\
(0.049)\end{array}$ & & & \\
\hline$\%$ coworkers whose ethnicity differs & & & $\begin{array}{c}\mathbf{0 . 0 0 1} \\
(0.027)\end{array}$ & $\begin{array}{l}-0.001 \\
(0.030)\end{array}$ & $\begin{array}{l}-0.013 \\
(0.027)\end{array}$ \\
\hline$\%$ other dept. managers whose ethnicity differs & & & & $\begin{array}{l}-0.001 \\
(0.026)\end{array}$ & \\
\hline$\%$ other employees whose ethnicity differs & & & & $\begin{array}{c}0.033 \\
(0.099)\end{array}$ & \\
\hline Observations & 2201 & 2198 & 2201 & 2098 & 2201 \\
\hline R-squared & 0.16 & 0.16 & 0.16 & 0.17 & 0.19 \\
\hline IDENTIFICATION STRATEGY: & $\begin{array}{l}\text { Store fixed } \\
\text { effects }\end{array}$ & $\begin{array}{l}\text { Store fixed } \\
\text { effects }\end{array}$ & $\begin{array}{l}\text { Store fixed } \\
\text { effects }\end{array}$ & $\begin{array}{c}\text { store FEs + } \\
\text { \%Hispanic } \\
\text { of others in } \\
\text { store }\end{array}$ & $\begin{array}{c}\text { store FEs + } \\
\text { Store- } \\
\text { specific } \\
\text { trends }\end{array}$ \\
\hline
\end{tabular}

Notes: Estimates from linear probability models in which dependent variable $=1$ if the employee transferred to another store within the next year. See also notes for Table 7. 